\title{
Cannabinoid-hypocretin cross-talk in the central nervous system: what we know so far
}

\author{
África Flores, Rafael Maldonado and Fernando Berrendero* \\ Laboratory of Neuropharmacology, Department of Experimental and Health Sciences, Universitat Pompeu Fabra, Barcelona, Spain
}

Edited by:

Christopher J. Winrow, Merck, USA

Reviewed by:

Thomas Heinbockel, Howard University College of Medicine, USA

Regina A. Mangieri, The University

of Texas at Austin, USA

${ }^{*}$ Correspondence:

Fernando Berrendero, Laboratory of Neuropharmacology, Department of

Experimental and Health Sciences,

Universitat Pompeu Fabra, PRBB,

C/ Doctor Aiguader 88, 08003

Barcelona, Spain

e-mail: fernando.berrendero@

upf.edu
Emerging findings suggest the existence of a cross-talk between hypocretinergic and endocannabinoid systems. Although few studies have examined this relationship, the apparent overlap observed in the neuroanatomical distribution of both systems as well as their putative functions strongly point to the existence of such cross-modulation. In agreement, biochemical and functional studies have revealed the existence of heterodimers between CB1 cannabinoid receptor and hypocretin receptor-1, which modulates the cellular localization and downstream signaling of both receptors. Moreover, the activation of hypocretin receptor-1 stimulates the synthesis of 2-arachidonoyl glycerol culminating in the retrograde inhibition of neighboring cells and suggesting that endocannabinoids could contribute to some hypocretin effects. Pharmacological data indicate that endocannabinoids and hypocretins might have common physiological functions in the regulation of appetite, reward and analgesia. In contrast, these neuromodulatory systems seem to play antagonistic roles in the regulation of sleep/wake cycle and anxiety-like responses. The present review attempts to piece together what is known about this interesting interaction and describes its potential therapeutic implications.

Keywords: hypocretinergic system, endocannabinoid system, heteromerization, reward, energy balance, antinociception, sleep/wake cycle

\section{ENDOCANNABINOIDS AND HYPOCRETINS: TWO ESSENTIAL NEUROMODULATORS}

The extracts of the plant Cannabis sativa contain about 60 active compounds of which $\Delta^{9}$-tetrahydrocannabinol (THC) is the main psychoactive component (Hall and Degenhardt, 2009). Although it was initially believed that THC exerted its effects by interacting with the plasma membrane due to its high lipophilic nature (Martin, 1986), the site of action of this substance is an endogenous neuromodulatory system termed endogenous cannabinoid system. The endocannabinoid system is constituted by membrane receptors, their fatty-acid derived endogenous ligands and the enzymatic machinery that synthesizes and degrades these lipidic neurotransmitters.

At least two different cannabinoid receptors have been cloned, termed $\mathrm{CB} 1$ and $\mathrm{CB} 2$ receptors, which share only $44 \%$ amino acid (AA) sequence homology (Matsuda et al., 1990; Munro et al., 1993). The distribution of CB1 and CB2 is markedly different: $\mathrm{CB} 1$ is the most abundant G-protein coupled receptor (GPCR) in the central nervous system (CNS) (Herkenham et al., 1990), while CB2 is mainly found in immune cells and peripheral tissues (Munro et al., 1993), although some CB2 expression is detected in the brainstem, cortex and cerebellar neurons and microglia (Núñez et al., 2004; Van Sickle et al., 2005). In addition, cannabinoid compounds are able to activate other "non-CB" receptors, such as GPR55, peroxisome proliferator-activated receptors (PPARs), and vanilloid type TRP channels (Pertwee et al., 2010; Kukkonen, 2011).
Endocannabinoids are arachidonic acid-containing messengers generated by phospholipase action, produced on demand at the site of need and are not usually stored in vesicles like classical neurotransmitters ( $\mathrm{Di}$ Marzo, 2009). The most important endocannabinoids identified are $\mathrm{N}$-arachidonylethanolamine (anandamide) and 2arachidonylglycerol (2-AG) (Devane et al., 1992; Sugiura et al., 1995), although other ligands such as noladin ether and virodhamide have also been detected (Hanus et al., 2001; Porter et al., 2002). Endocannabinoids are known to act as retrograde regulators of synaptic transmission. Thus, after being synthesized in postsynaptic neurons in response to a depolarization-induced increase in intracellular $\mathrm{Ca}^{2+}$, and released to act on CB1 expressed in presynaptic and/or nearby neurons, endocannabinoids attenuate presynaptic depolarization and subsequent neurotransmitter release (Kano et al., 2009). After synthesis and release, endocannabinoid signaling is terminated by reuptake into both neurons and glia followed by intracellular hydrolysis of anandamide and 2-AG, carried out by fatty acid amide hydrolase (FAAH) and monoacylglycerol lipase (MAGL), respectively (Muccioli, 2010).

It has been extensively reported that the endocannabinoid system reciprocally modulates other neurotransmitter systems. The interaction with the endogenous opioid system is the most explored of these cross-talks (Robledo et al., 2008; Parolaro et al., 2010), but pharmacological and biochemical data also reveal an interplay at both molecular and functional levels with other 
neurotransmitters, such as the dopaminergic and adenosinergic systems (Carriba et al., 2007; Ferré et al., 2009; Fernández-Ruiz et al., 2010). Interestingly, emerging evidence points to a crossmodulation between endocannabinoid and hypocretinergic systems, providing a new range of potential therapeutic applications to currently existing drugs targeting these systems.

Hypocretin-1/orexin-A and hypocretin-2/orexin-B are two neuropeptides proteolytically cleaved from the same precursor, prepro-hypocretin/prepro-orexin (de Lecea et al., 1998; Sakurai et al., 1998). Hypocretin-1 is constituted by 33 AA and posttranslationally stabilized by two intrachain disulphide bonds, whereas hypocretin-2 consists of $28 \mathrm{AA}$ and remains as a linear peptide (Sakurai et al., 1998). As other neuromodulatory peptides, hypocretins are stored at the axon terminals within secretory vesicles, which release their content in a $\mathrm{Ca}^{2+}$-dependent manner (de Lecea et al., 1998). In contrast to endocannabinoids, hypocretins act mainly as neuroexcitatory modulators. Hypocretins induce neuroexcitation at both pre- and postsynaptic levels: activation of presynaptic $\mathrm{Ca}^{2+}$ channels facilitates neurotransmitter release (van den Pol et al., 1998; Li et al., 2002), and regulation of diverse postsynaptic ion channels leads to postsynaptic depolarization (Kukkonen et al., 2002). However, few studies also report hypocretin-induced synaptic inhibition, although the mechanisms underlying this effect remain unclear (Davis et al., 2003; Ma et al., 2007).

So far, two hypocretin receptors with $64 \%$ AA sequence homology have been identified: hypocretin or orexin receptor1 (HcrtR1/OxR1) and hypocretin or orexin receptor-2 (HcrtR2/OxR2) (Sakurai et al., 1998). HcrtR1 displays a 10-fold higher affinity for hypocretin-1 than hypocretin-2, whereas HcrtR2 has equal affinity for both peptides (Smart et al., 2001; Ammoun et al., 2003). Hypocretin-expressing neurons are located exclusively in the hypothalamus, especially in the lateral (LH), perifornical (PFA), and dorsomedial areas (DMH) (de Lecea et al., 1998; Peyron et al., 1998; Sakurai et al., 1998). Despite representing a relatively small population of cells, hypocretinergic neurons send projections widely through the entire neuroaxis of the CNS (Peyron et al., 1998), suggesting that hypocretins modulate the activity of multiple neurotransmitter systems and therefore regulate diverse physiological functions.

\section{COMMON CHARACTERISTICS BETWEEN ENDOCANNABINOID AND HYPOCRETINERGIC SYSTEMS}

Anatomical studies have found that CB1 and HcrtRs show an overlapping distribution in several areas of the CNS (Hervieu et al., 2001; Marcus et al., 2001; Mackie, 2005), suggesting a common role in some physiological functions (Figure 1). Thus, HcrtR1 and HcrtR2, as well as CB1, are widely expressed within the entire hypothalamus, denoting an important function of these systems in energy homeostasis and central regulation of neuroendocrine and autonomic functions (Wittmann et al., 2007; Tsujino and Sakurai, 2009). Both receptors are also found in diverse areas of the mesocorticolimbic system, such as the ventral tegmental area (VTA), the nucleus accumbens (NAc), the prefrontal cortex (PFC), the septal nuclei and the amygdaloid nuclei, supporting the regulation of natural reward and addiction processes by endocannabinoid and hypocretinergic systems
(Maldonado et al., 2006; Aston-Jones et al., 2010; Plaza-Zabala et al., 2012). The presence of CB1, HcrtR1, and HcrtR2 within diverse brainstem nuclei, including the raphe nuclei, the locus coeruleus, the reticular formation and the periaqueductal gray $(\mathrm{PAG})$, is in agreement with the role of these neuromodulators with the regulation of anxiety-like responses, sleep/wake cycle and nociception (Eriksson et al., 2010; Häring et al., 2012; WilsonPoe et al., 2012). Nevertheless, the existence of cross-reactivity problems with HcrtR antibodies has hindered the precise location of these receptors (Kukkonen, 2012). Hence, although specific CB1 expression among different neuronal populations has been well characterized (Mackie, 2005), the location of HcrtRs is certainly known only at the level of brain structure since it has been confirmed by in situ hybridization studies (Hervieu et al., 2001). As a consequence, direct synaptic connections between CB1 and HcrtRs are not well defined. On the other hand, recent studies have detected certain multifocal expression of CB2 in the brain at levels much lower than those of CB1 receptors (Gong et al., 2006; Onaivi et al., 2006). Among these CB2 expression foci, hippocampus, amygdala and PAG are potentially the most relevant areas to the study of the cannabinoid-hypocretinergic interplay.

CB1 and CB2, as well as HcrtR1 and HcrtR2, belong to the rhodopsin subfamily of GPCR superfamily. The cellular signals triggered upon cannabinoid receptor activation differ from those initiated following the stimulation of hypocretin receptor. However, it seems that diverse signaling pathways are common for cannabinoid and hypocretin receptors (Demuth and Molleman, 2006) (Figure 2). Both CB1 and CB2 receptors are associated with the Gi/o family of G-proteins, as most cannabinoid effects are blocked by pertussis toxin (PTX) (Howlett et al., 1986; Slipetz et al., 1995). Subsequent functional inhibition of adenylyl cyclase (AC) activity and decreased cAMP production has been observed in most tissues and cells investigated (Howlett et al., 2002). However, CB1 has been shown to stimulate AC when Gi protein is hardly available, such as under PTX treatment or sequestering by other GPCR receptor activation, indicating that CB1 may be able to couple Gs under these particular experimental conditions (Glass and Felder, 1997; Jarrahian et al., 2004). The modulation of voltage-dependent ion channels by $\mathrm{CB} 1$ activation is thought to underlie the cannabinoid-induced inhibition of neurotransmitter release, although it seems that CB1-independent mechanisms of ion channel modulation might also exist (Demuth and Molleman, 2006). CB1 activates inward-rectifying $\mathrm{K}^{+}$(Kir) and A-type $\mathrm{K}^{+}$channels, triggering the plasmatic membrane repolarization (Deadwyler et al., 1995; Vásquez et al., 2003). This was shown to be mediated by CB1 receptor-mediated reduction in cAMP levels and PKA activation (Deadwyler et al., 1995; Hampson et al., 1995). Additionally, CB1 inhibits N-, P/Q- and L-type voltagegated $\mathrm{Ca}^{2+}$ channels, leading to a decrease in $\mathrm{Ca}^{2+}$ influx, mostly by direct $\mathrm{G} \beta \gamma$ interaction with the channel (Howlett et al., 2002). $\mathrm{CB} 1$ and $\mathrm{CB} 2$ activation also leads to the phosphorylation and activation of the MAP kinase cascade (Bouaboula et al., 1995, 1997; Derkinderen et al., 2001), which regulates neuronal gene expression and synaptic plasticity. Diverse transduction pathways leading to activation of different MAP kinases (ERK1/2, JNK, ERK5, and p38) have been proposed, depending on the cell type and the stimulus. MAP kinase activation is mediated 

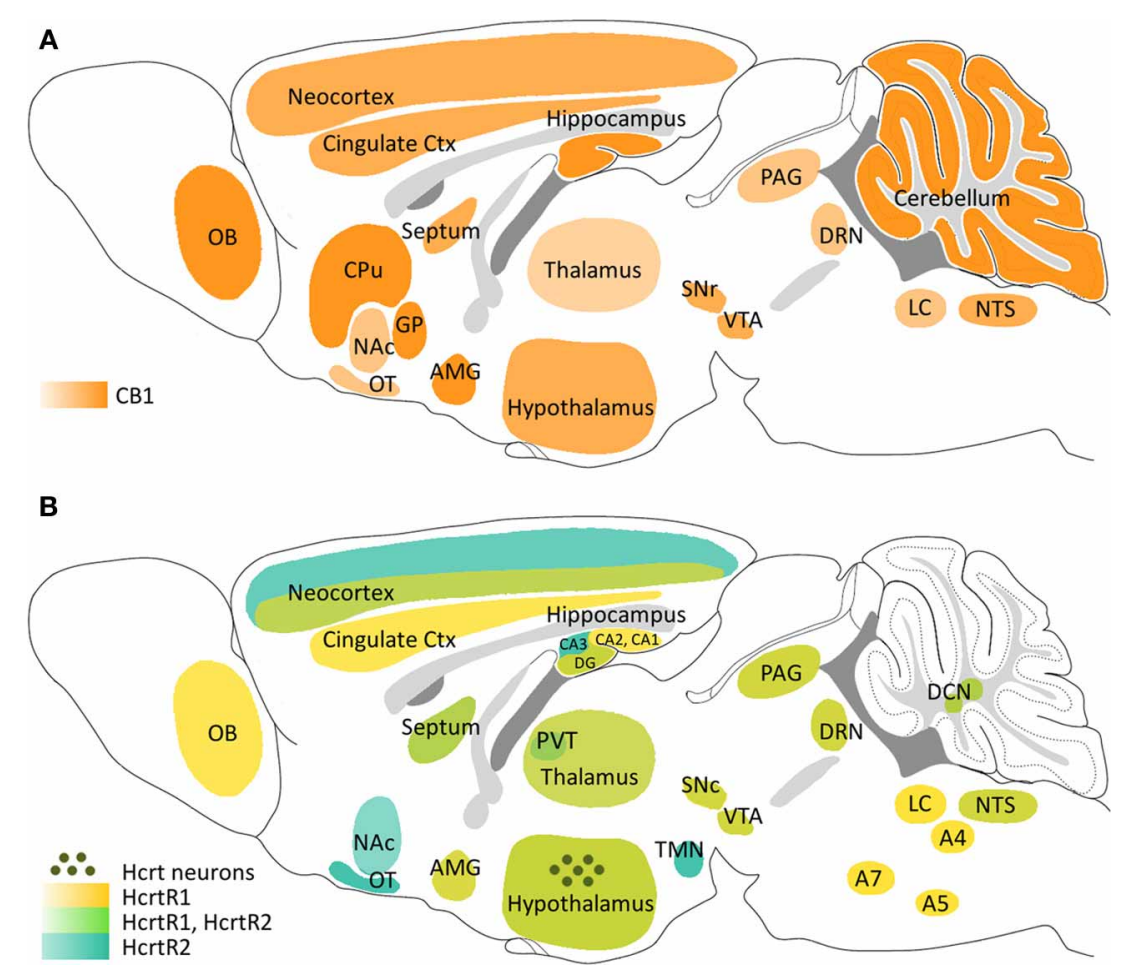

FIGURE 1 |Schematic representation of the main areas expressing CB1, HertR1 and HcrtR2 in the mouse brain and location of hypocretinergic neurons. (A) CB1 receptor distribution. (B) HcrtR1 and HcrtR2 distribution and localization of hypocretinergic neurons. A4, A5, A7, pons cell groups; AMG, amygdala; CPu, caudate putamen; Ctx, cortex; DCN, deep cerebellar nuclei; DRN, dorsal raphe nucleus; GP, globus pallidus; LC, locus coeruleus; NAc, nucleus accumbens; NTS, nucleus of the solitary tract; OB, olfactory bulb; OT, olfactory tubercle; PAG, periaqueductal gray; PVT, paraventricular nucleus of thalamus; SNc, substantia nigra pars compacta; SNr, substantia nigra pars reticulata; TMN, tuberomammillary nucleus; VTA, ventral tegmental area. by PI3K pathway in CHO cells (Galve-Roperh et al., 2002), PC3 cells (Sánchez et al., 2003) and astrocytoma cells (Gómez del Pulgar et al., 2000), through the protein kinase B (PKB/Akt) phosphorylation and Raf-1 activation. Some studies also suggest that decrease in cAMP levels, and consequently reduced inhibitory c-Raf phosphorylation by PKA activity, may participate in the stimulatory effects of CB1 activation on the MAP kinase pathway (Melck et al., 1999; Davis et al., 2003).

On the other hand, both hypocretin receptors are coupled to Gq proteins, which induce the activation of PLC and production of the second messengers DAG and IP3 from PIP2. This triggers the activation of PKC, which phosphorylates and modulates effector ion channels leading to $\mathrm{Ca}^{2+}$ entrance (van den Pol et al., 1998; Eriksson et al., 2001), as well as further IP3mediated entry via store-operated $\mathrm{Ca}^{2+}$ channels (Kukkonen and Akerman, 2001; Larsson et al., 2005). In addition, membrane depolarization is facilitated by activation of $\mathrm{Na}^{+} / \mathrm{Ca}^{2+}$ exchanger (Burdakov et al., 2003), increase of non-selective cation channel conductances (Liu et al., 2002; Yang and Ferguson, 2002; Murai and Akaike, 2005) and/or blockade of Kir channels (Hwang et al., 2001; Yang and Ferguson, 2003; Ishibashi et al., 2005). It remains to be further elucidated by using selective antagonists the identification of the receptor subtype mediating these effects. Additionally, some studies of lipid signaling pathways activated by HcrtR1-expressing CHO cells have also revealed coupling to PLD and PLA2 (Turunen et al., 2012). Besides, stimulation of both hypocretin receptors has been suggested to modulate AC activity by coupling other G-proteins, such as Gs-protein as shown by AC activation and cAMP production in neurons (Gorojankina et al., 2007) and astrocytes (Woldan-Tambor et al., 2011), or Gi-protein as observed by hypocretin-1 inhibition of AC via Gicoupling (Holmqvist et al., 2005; Urbańska et al., 2012). Similar to cannabinoids, hypocretin signaling also activates the MAP kinase pathway. Thus, HcrtR1 challenge leads to ERK1/2 and p38 kinase phosphorylation (Ammoun et al., 2006a). Downstream effectors contributing to ERK1/2 activation after HcrtR1 stimulation include at least $\mathrm{Ca}^{2+}$ influx, PLC/PKC, Ras, Src, and PI3K (Ammoun et al., 2006b). Similar results have been recorded in an HcrtR2 expression system (Tang et al., 2008). Thus, cannabinoid and hypocretinergic signaling differ in their modulation of ion channel currents and AC activity, while they converge in the activation of the MAP kinase pathway.

\section{MOLECULAR INTERACTIONS BETWEEN CB1 AND HcrtR1}

Direct CB1-HcrtR1 interaction was first proposed in 2003 (Hilairet et al., 2003). Indeed, a 100-fold increase in the potency of hypocretin-1 to activate the ERK signaling was observed when CB1 and HcrtR1 were co-expressed in CHO cells. This effect required a functional $\mathrm{CB} 1$ receptor as evidenced by the blockade of hypocretin response by the CB1 antagonist rimonabant, 


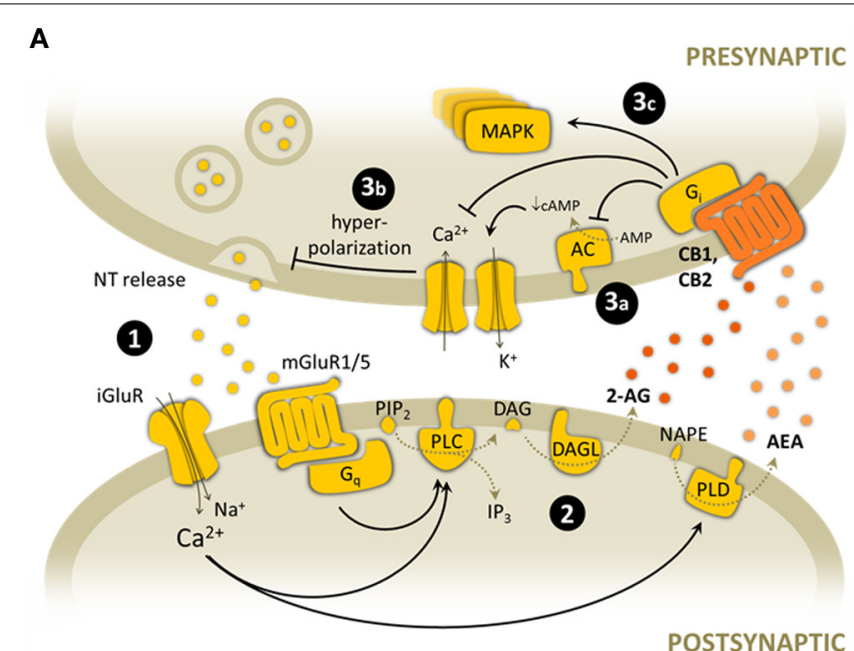

FIGURE 2 | Overview of the main synaptic signaling mechanisms of endocannabinoid and hypocretinergic systems. (A)

Endocannabinoid-mediated synaptic signaling. (1) Glutamate is released from presynaptic terminals and stimulates both ionotropic and metabotropic glutamate receptors, leading to postsynaptic depolarization through $\mathrm{Ca}^{2+}$ entrance and Gq-protein activation. (2) High $\mathrm{Ca}^{2+}$ concentration stimulates endocannabinoid synthesis through PLC and PLD. 2-AG synthesis is also mediated by Gq-protein activation. (3) Endocannabinoids are released to the synaptic cleft and activate CB1 and CB2 presynaptic receptors. Some of the main downstream consequences of $\mathrm{CB}$ receptor activation and subsequent Gi-protein stimulation are: (3a) inhibition of $A C$ activity, (3b) membrane hyperpolarization after modulation of $\mathrm{K}+$ and $\mathrm{Ca} 2+$ channels, and subsequent inhibition of NT release, (3c) activation of protein kinase cascades such as MAPK pathway. (B) Hypocretin-mediated synaptic signaling. (1) Hypocretins are released from presynaptic terminals and
B

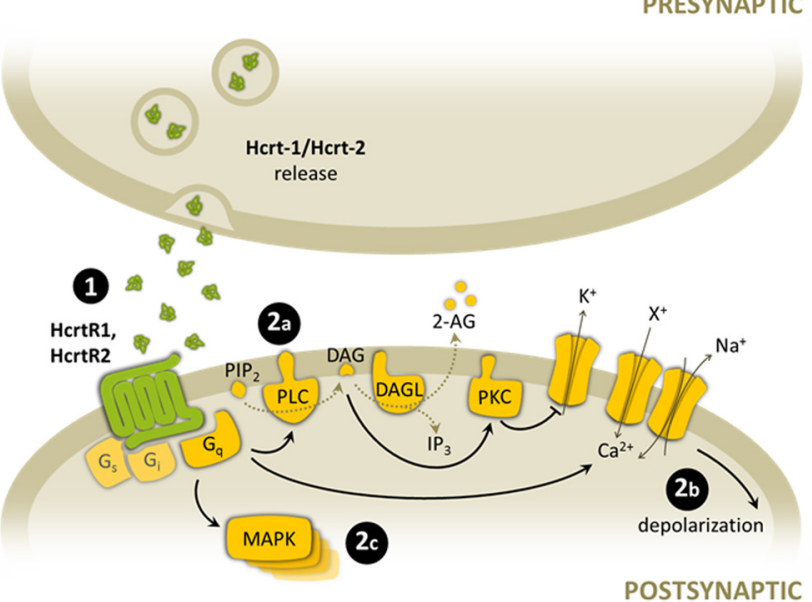

activate postsynaptic HcrtR1 and HcrtR2. (2) HcrtR stimulation is mainly associated with Gq-protein activation, but it can activate also other G-protein subtypes. Some of the main downstream consequences of HcrtR activation and subsequent Gq-protein stimulation are: (2a) activation of PLC activity, and subsequent DAG and 2-AG synthesis (2b) membrane depolarization after modulation of $\mathrm{K}+$ channels, non-specific cationic channels and

$\mathrm{Na}^{+} / \mathrm{Ca}^{2+}$ exchanger, (2c) activation of protein kinase cascades such as MAPK pathway. NT, neurotransmitter; iGluR, ionotropic glutamate receptor; mGluR, metabotropic glutamate receptor; PIP2, phosphatidylinositol bisphosphate; DAG, diacylglicerol; 2-AG, 2-arachidonoylglycerol; NAPE,

$\mathrm{N}$-arachidonoyl-phosphatidylethanolamine; AEA, anandamide; PLC, phospholipase C; DAGL, diacylglycerol lipase; PLD, phospholipase D; AC, adenyl cyclase; cAMP, cyclic AMP; MAPK, mitogen-activated protein kinase; Hcrt-1, hypocretin-1; Hcrt-2, hypocretin-2; PKC, protein kinase $\mathrm{C} ; \mathrm{X}^{+}$, unspecific cation. and was blocked by PTX, suggesting a Gi-mediated potentiation. Based on electron microscopy colocalization, the authors inferred the formation of heteromeric complexes by HcrtR1 and CB1 that might explain the enhancement in hypocretin-induced ERK signaling (Hilairet et al., 2003). Importantly, in these colocalization studies specificity problems with anti-HcrtR1 antibodies were avoided by tagging the $\mathrm{N}$-terminus of HcrtR1 with the cMyc epitope, monitoring its expression using mouse monoclonal anti-Myc antibodies. The possible existence of CB1-HcrtR1 heteromerization has been further assessed by co-expressing these GPCRs in HEK293 cells (Ellis et al., 2006). In this study, rimonabant caused a decrease in the potency of hypocretin-1 to activate the MAP kinases ERK1/2 in cells co-expressing both receptors. Similarly, the HcrtR1 antagonist SB674042 reduced in these cells the potency of the CB1 agonist WIN55,212-2 to phosphorylate ERK1/2. Additionally, co-expression of CB1 and HcrtR1 resulted in coordinated trafficking of these GPCRs. Indeed, following inducible expression in HEK293 cells, HcrtR1 was mainly located in the cell surface, while CB1 constitutive expression resulted in a distribution pattern in intracellular vesicles consistent with spontaneous, agonist-independent internalization. When both receptors were co-expressed, HcrtR1 appeared to be recycled in intracellular vesicles, adopting the location of CB1 inherent to this model. When treated with rimonabant or with SB674042, both
CB1 and HcrtR1 were re-localized at the cell surface. The possible direct protein-protein interaction between CB1 and HcrtR1 deduced from these data was tested by performing single cell fluorescence resonance energy transfer (FRET) imaging studies, which confirmed that CB1 and HcrtR1 were close enough to form veritable heteromers (Ellis et al., 2006). Recently, the same group has demonstrated further evidence of such heteromerization by covalently labeling the extracellular domains of CB1 and HcrtR1 with SNAP-tag ${ }^{\circledR}$ and CLIP-tag ${ }^{\mathrm{TM}}$ labeling systems, which consist in two polypeptides that can be fused to a protein of interest and further covalently tagged with a suitable ligand (i.e., a fluorescent dye), allowing a reliable monitorization of these heteromers at the cell surface (Ward et al., 2011a,b). In this study, a higher potency of hypocretin-1 to regulate CB1-HcrtR1 heteromer compared with the HcrtR1-HcrtR1 homomer was reported (Ward et al., 2011b). These data provide unambiguous identification of CB1-HcrtR1 heteromerization, which has a substantial functional impact.

Besides the heteromerization, an additional mechanism has been proposed to explain the increase in the potency of hypocretin-1 to activate the ERK pathway in the presence of CB1 (Jäntti et al., 2013; Kukkonen and Leonard, 2013). Recent studies report that HcrtR1-expressing $\mathrm{CHO}$ cells may release 2AG in response to hypocretin-1 stimulation. In these cells, the 
activation of PLC is responsible for DAG production, which in turn is used by diacylglycerol lipase (DAGL) as a substrate for 2-AG production (Turunen et al., 2012). Taking into account that both HcrtR1 and CB1 activate ERK upon ligand binding (Bouaboula et al., 1995; Ammoun et al., 2006a), it is possible that 2-AG-mediated stimulation of $\mathrm{CB} 1$ could contribute to increase the potency of hypocretin-1 signaling in the $\mathrm{CHO}$ cell expression system. In addition, recent evidence supports that endocannabinoids may act in an auto- or paracrine manner, and the influence of endogenously produced endocannabinoids when introducing Gq-coupled receptors to the expression system cannot be discarded (Howlett et al., 2011). Indeed, it has been demonstrated that HcrtR1 stimulation elevates 2-AG in biologically relevant quantities, activating $\mathrm{CB} 1$ receptors in nearby cells (Turunen et al., 2012). Importantly, this hypocretin-induced endocannabinoid release might shed light on the mechanisms by which hypocretins mediate synaptic inhibition in certain conditions.

\section{FUNCTIONAL INTERACTION BETWEEN CANNABINOIDS AND HYPOCRETINS: EMERGING STUDIES}

Despite anatomical, biochemical and pharmacological evidence supporting the possible existence of a link between cannabinoids and hypocretins, few studies have directly evaluated this crosstalk at the functional level (Table 1). Current research suggests their mutual involvement in the regulation of several physiological responses including appetite, reward, sleep/wake cycle and nociception.

\section{APPETITE AND ENERGY BALANCE}

The regulation of energy balance is determined by the control of food intake and energy expenditure. The so-called homeostatic control of energy balance is exerted in response to variations in the nutritional status and energy stores and is autonomic or involuntary, whereas the non-homeostatic control has a cognitive component strongly influenced by the hedonic aspects of eating (Saper et al., 2002; Berthoud, 2007) (see section Regulation of the brain rewarding system). Interestingly, endocannabinoid and hypocretinergic systems appear to be involved in both processes. Recently, the LH has been suggested to constitute a bridge between homeostatic and non-homeostatic brain areas involved in energy balance regulation. Indeed, this region connects the hypothalamic regulators of energy balance [e.g., the arcuate nucleus (Arc) and the paraventricular nucleus (PVN)], to the NAc and the VTA, two key parts of the brain reward system (Berthoud, 2007; Richard et al., 2009).

Endocannabinoids, as well as systemic administration of cannabinoid agonists, stimulate food intake (Williams et al., 1998; Williams and Kirkham, 1999). These effects are mediated by CB1 receptor. Indeed, rimonabant reduces the consumption of standard food in food-deprived animals (Colombo et al., 1998), and CB1-deficient mice consume less food than wild-type littermates and are resistant to diet-induced obesity (Di Marzo et al., 2001; Cota et al., 2003). Accordingly, fasting increases levels of anandamide and 2-AG in the limbic forebrain and, to a lesser extent, of 2-AG in the hypothalamus, whereas feeding declines endocannabinoid levels in these areas (Kirkham et al., 2002). Likewise, central administration of hypocretin-1 or hypocretin-2 stimulates food consumption, whereas systemic administration of the HcrtR1 antagonist SB334867 reduces feeding (Sakurai et al., 1998; Haynes et al., 2000; Shiraishi et al., 2000). Furthermore, preprohypocretin mRNA is upregulated following fasting (Sakurai et al., 1998) as well as in obese mice during food restriction (Yamanaka et al., 2003). Interestingly, pretreatment with a non-anorectic dose of rimonabant blocks orexigenic actions of hypocretin-1 administered by intracerebroventricular route (icv) in pre-fed rats, suggesting that hypocretin-1 exerts its orexigenic action through CB1 receptor activation (Crespo et al., 2008). However, the increase induced by hypocretin-1 in food intake correlates with an increase in locomotion and wakefulness (Yamanaka et al., 1999; Crespo et al., 2008), leading to the hypothesis that the primary function of this system is promoting arousal in response to food deprivation, which would facilitate the food consumption (Yamanaka et al., 2003; Cason et al., 2010).

One of the main hypothalamic regulators of appetite is the Arc-PVN axis (Girault et al., 2012) (Figure 3). Circulating levels of leptin, produced by adipocytes in proportion to the adipose mass, inhibit neurons in the Arc that co-express the orexigenic neurotransmitters neuropeptide Y (NPY) and agoutirelated peptide (AgRP), whereas they activate the anorexic pro-opiomelanocortin (POMC) neurons that co-express cocaineamphetamine-related transcripts (CART). Grehlin, released during fasting, produces the opposite effect on these neurons. NPY/AgRP and POMC/CART neurons convey their information to second-order neurons in the PVN and $\mathrm{LH}$, such as the corticotrophin-releasing hormone $(\mathrm{CRH})$, the melaninconcentrating hormone $(\mathrm{MCH})$ and hypocretin neurons (Elias et al., 1998). Emerging evidence suggests that NPY and hypocretin neurons have reciprocal excitatory connections. Thus, reduced plasma glucose and leptin and increased grehlin levels induce fasting-related arousal by causing an activation of NPY neurons finally increasing the firing of hypocretin neurons. Additionally, it seems that increased hypocretinergic activity during sleep deprivation may activate NPY neurons resulting in hyperphagia independent from peripheral endocrine and metabolic signaling (Yamanaka et al., 2000).

$\mathrm{CB} 1$ receptors colocalize with $\mathrm{CART}, \mathrm{MCH}$ and hypocretin neurons (Cota et al., 2003). Acute administration of rimonabant induces c-fos in all these neuronal populations including hypocretinergic cells, increases CART and decreases NPY expression, consistent with its anorexic effect. However, the CB1 antagonist has no effect in hypocretin expression suggesting that hypocretins are not likely to be the main mediators of cannabinoid hypothalamic orexigenic effects (Verty et al., 2009). An interesting electrophysiological study in mouse reveals that the cannabinoid agonist WIN55-212,2 depolarizes MCH cells increasing spike frequency while reducing spontaneous firing of hypocretin cells (Huang et al., 2007). CB1-mediated depolarization of $\mathrm{MCH}$ cells was a consequence of cannabinoid action on axons arising from $\mathrm{LH}$ local inhibitory cells, resulting in reduced synaptic GABA release on $\mathrm{MCH}$ neurons. On the contrary, $\mathrm{CB} 1$ agonists hyperpolarized hypocretin cells by presynaptic attenuation of glutamate release (Huang et al., 2007). These results are in line with the idea that some of the orexigenic actions of cannabinoids could be explained 
Table 1 | Studies investigating the interaction between endocannabinoid and hypocretinergic systems.

\begin{tabular}{|c|c|c|c|c|c|}
\hline $\begin{array}{l}\text { Functional } \\
\text { interaction }\end{array}$ & Tools & & Techniques & Main result & References \\
\hline \multirow[t]{3}{*}{ Energy balance } & in vivo (rat) & $\begin{array}{l}\text { Hypocretin-1 } \\
\text { CB1 antagonist }\end{array}$ & Food intake monitoring & $\begin{array}{l}\text { Subeffective systemic rimonabant } \\
\text { attenuates food intake induced by } \\
\text { central hypocretin-1 }\end{array}$ & $\begin{array}{l}\text { Crespo et al., } \\
2008\end{array}$ \\
\hline & Rat tissue & CB1 antagonist & $\begin{array}{l}\text { LH Immunofluorescence } \\
\text { qRT-PCR } \\
\text { Western Blot }\end{array}$ & $\begin{array}{l}\text { Rimonabant administration induces } \\
\text { Fos expression in hypocretin, } \mathrm{MCH} \text {, } \\
\text { MSH and CART neurons, but does } \\
\text { not affect hypocretin mRNA or } \\
\text { protein levels }\end{array}$ & $\begin{array}{l}\text { Verty et al., } \\
2009\end{array}$ \\
\hline & $\begin{array}{l}\text { ex vivo } \\
\text { (mouse) }\end{array}$ & $\begin{array}{l}\text { Obese ob/ob mice } \\
\text { High-fat diet } \\
\text { CB agonist } \\
\text { Leptin } \\
\text { mTOR inhibitor }\end{array}$ & $\begin{array}{l}\text { Confocal, electron microscopy } \\
\text { LH electrophysiology } \\
\text { LH immunofluorescence }\end{array}$ & $\begin{array}{l}\text { In obesity, hypocretinergic neurons } \\
\text { overexpress DAGL and receive } \\
\text { predominantly inhibitory, instead of } \\
\text { excitatory, CB1-expressing inputs. } \\
\text { These alterations are reversed by } \\
\text { leptin administration }\end{array}$ & $\begin{array}{l}\text { Cristino et al., } \\
2013\end{array}$ \\
\hline \multirow[t]{3}{*}{$\begin{array}{l}\text { Reward and } \\
\text { Cannabis } \\
\text { dependence }\end{array}$} & in vivo (rat) & $\begin{array}{l}\text { Cholinergic agonist } \\
\text { HcrtR1 antagonist } \\
\text { CB1 antagonist }\end{array}$ & Conditioned place preference & $\begin{array}{l}\text { CPP induced by LH-chemical } \\
\text { stimulation requires HcrtR1 and } \\
\text { CB1 receptor signaling in the VTA }\end{array}$ & $\begin{array}{l}\text { Taslimi et al., } \\
2011\end{array}$ \\
\hline & $\begin{array}{l}\text { in vivo } \\
\text { (mouse) }\end{array}$ & $\begin{array}{l}\text { HcrtR1 knockout mice } \\
\text { CB agonists } \\
\text { HcrtR1 and HcrtR2 } \\
\text { antagonists }\end{array}$ & $\begin{array}{l}\text { Drug self-administration } \\
\text { LH immunofluorescence } \\
\text { In vivo microdyalisis }\end{array}$ & $\begin{array}{l}\text { Rewarding properties of } \\
\text { cannabinoids are modulated by } \\
\text { HcrtR1 and activate LH } \\
\text { hypocretinergic neurons. } \\
\text { HcrtR1 regulates THC-induced } \\
\text { dopamine release in } \mathrm{Nac}\end{array}$ & $\begin{array}{l}\text { Flores et al., } \\
2013\end{array}$ \\
\hline & $\begin{array}{l}\text { in vivo } \\
\text { (human) }\end{array}$ & - & $\begin{array}{l}\text { Peripheral blood gene } \\
\text { expression and promoter } \\
\text { metylation study }\end{array}$ & $\begin{array}{l}\text { THC-smokers show decreased } \\
\text { hypocretin expression when } \\
\text { compared to cigarette-smokers }\end{array}$ & $\begin{array}{l}\text { Rotter et al., } \\
2012\end{array}$ \\
\hline \multirow[t]{2}{*}{$\begin{array}{l}\text { Sleep/wake } \\
\text { cycle }\end{array}$} & in vivo (rat) & CB1 agonist and antagonist & $\begin{array}{l}\text { EEG and EMG monitoring } \\
\text { LH immunofluorescence }\end{array}$ & $\begin{array}{l}\text { Intra-LH administration of 2-AG } \\
\text { increases REM sleep and cFos } \\
\text { expression in } \mathrm{MCH} \text { neurons, but } \\
\text { does not affect cFos expression in } \\
\text { hypocretinergic neurons }\end{array}$ & $\begin{array}{l}\text { Pérez-Morales } \\
\text { et al., } 2013\end{array}$ \\
\hline & ex vivo (rat) & $\begin{array}{l}\text { Hypocretin-2 } \\
\text { CB1 agonist and antagonist } \\
\text { PLC and DAGL inhibitors }\end{array}$ & DRN electrophysiology & $\begin{array}{l}\text { Hypocretin-2 inhibits glutamate } \\
\text { release to DRN serotonergic } \\
\text { neurons through retrograde 2-AG } \\
\text { signaling }\end{array}$ & $\begin{array}{l}\text { Haj-Dahmane } \\
\text { and Shen, } 2005\end{array}$ \\
\hline $\begin{array}{l}\text { Cellular and } \\
\text { molecular } \\
\text { interaction }\end{array}$ & $\begin{array}{l}\text { ex vivo } \\
\text { (mouse) }\end{array}$ & $\begin{array}{l}\text { CB agonist ad antagonist } \\
\text { GABAa antagonist } \\
\text { iGluR antagonist }\end{array}$ & $\begin{array}{l}\text { LH electrophysiology } \\
\text { Immunocytochemistry }\end{array}$ & $\begin{array}{l}\text { Cannabinoids reduce activity of } \\
\text { hypocretin neurons by presynaptic } \\
\text { attenuation of glutamate release } \\
\text { and excite } \mathrm{MCH} \text { neurons by } \\
\text { presynaptic inhibition of GABA } \\
\text { release }\end{array}$ & $\begin{array}{l}\text { Huang et al., } \\
2007\end{array}$ \\
\hline
\end{tabular}


Table 1 | Continued

\begin{tabular}{|c|c|c|c|c|c|}
\hline \multirow{2}{*}{$\begin{array}{l}\text { Functional } \\
\text { interaction }\end{array}$} & \multicolumn{2}{|l|}{ Tools } & \multirow{2}{*}{$\begin{array}{l}\text { Techniques } \\
\begin{array}{l}\text { Confocal, electron microscopy } \\
\text { Intracellular signaling assays }\end{array}\end{array}$} & \multirow{2}{*}{$\begin{array}{l}\text { Main result } \\
\text { CB1-HcrtR1 coexpression } \\
\text { potentiates activation of the MAPK } \\
\text { pathway induced by hypocretin-1 }\end{array}$} & \multirow{2}{*}{$\begin{array}{l}\text { References } \\
\text { Hilairet et al., } \\
2003\end{array}$} \\
\hline & $\begin{array}{l}\text { in vitro (cell } \\
\text { culture) }\end{array}$ & $\begin{array}{l}\text { Hypocretin-1 } \\
\text { CB1 antagonist }\end{array}$ & & & \\
\hline & $\begin{array}{l}\text { in vitro (cell } \\
\text { culture) }\end{array}$ & $\begin{array}{l}\text { Hypocretin-1 } \\
\text { CB1 agonist and antagonist } \\
\text { HcrtR1 antagonist }\end{array}$ & $\begin{array}{l}\text { Redistribution assays } \\
\text { Epifluorescence microscopy } \\
\text { FRET imaging }\end{array}$ & $\begin{array}{l}\text { CB1-HcrtR1 heteromerization } \\
\text { results in coordinated alteration of } \\
\text { their cellular localization and } \\
\text { downstream signaling }\end{array}$ & Ellis et al., 2006 \\
\hline & $\begin{array}{l}\text { in vitro (cell } \\
\text { culture) }\end{array}$ & $\begin{array}{l}\text { CB1 agonist and antagonist } \\
\text { HcrtR1 antagonist }\end{array}$ & $\begin{array}{l}\text { Co-immunoprecipitation } \\
\text { SNAP and CLIP tagging } \\
\text { FRET imaging } \\
\text { Intracellular signaling assays }\end{array}$ & $\begin{array}{l}\text { Heteromultimerization of } \\
\text { CB1-HcrtR1 is confirmed by } \\
\text { co-immunoprecipitation and } \\
\text { SNAP/CLIP tagging. } \\
\text { Modulation of receptor } \\
\text { internalization and MAPK pathway } \\
\text { activation is also reproduced }\end{array}$ & $\begin{array}{l}\text { Ward et al., } \\
2011 a, b\end{array}$ \\
\hline & $\begin{array}{l}\text { in vitro (cell } \\
\text { culture) }\end{array}$ & $\begin{array}{l}\text { Hypocretin-1 and }-2 \\
\text { CB1 agonist and antagonist } \\
\text { DAGL and MAGL inhibitors } \\
\text { PLC, PLD and PLA inhibitors } \\
\text { HcrtR1 antagonist }\end{array}$ & Intracellular signaling assays & $\begin{array}{l}\text { HcrtR1 stimulation by hypocretin-1 } \\
\text { activates PLA2 and DAGL cascades } \\
\text { with subsequent release of AA and } \\
\text { 2-AG, which acts as paracrine } \\
\text { messenger through CB1 }\end{array}$ & $\begin{array}{l}\text { Turunen et al., } \\
2012\end{array}$ \\
\hline & $\begin{array}{l}\text { in vitro (cell } \\
\text { culture) }\end{array}$ & $\begin{array}{l}\text { Hypocretin-1 and }-2 \\
\text { CB1 antagonist } \\
\text { HcrtR1 antagonist DAGL and } \\
\text { MEK inhibitors }\end{array}$ & Intracellular signaling assays & $\begin{array}{l}\text { Release of 2-AG induced by } \\
\text { hypocretin-1 stimulates ERK } \\
\text { activity in neighboring } \\
\text { CB1-expressing cells. } \\
\text { HcrtR1-mediated ERK activity is } \\
\text { potentiated in cells coexpressing } \\
\text { CB1-HcrtR1 }\end{array}$ & $\begin{array}{l}\text { Jäntti et al., } \\
2013\end{array}$ \\
\hline
\end{tabular}

Abbreviations: IF, immunofluorescence; EPS, electrophysiology; drug self admin, drug self-administration; EF microscopy, epifluorescence microscopy; co-IP, coimmunoprecipitation.

by their synaptic effects on $\mathrm{MCH}$ neurons, which undoubtedly regulate energy balance (Pissios et al., 2006), and are not mediated by hypocretin neurons at least in physiological conditions. However, a recent study shows that the balance between CB1expressing glutamatergic and GABAergic inputs to hypocretin neurons is altered in obesity (Cristino et al., 2013). In leptinknockout (ob/ob) obese mice and in diet-induced obese mice, hypocretin neurons appear to receive predominantly inhibitory instead of excitatory CB1-expressing inputs (Cristino et al., 2013). In addition, hypocretin neurons overexpress the main enzyme that synthesizes 2-AG, DAGL $\alpha$, in these obesity models, in line with previous results reporting elevated hypothalamic levels of endocannabinoids in ob/ob mice and obese Zucker rats (Di Marzo et al., 2001). These alterations could result in a retrograde inhibition of these inhibitory CB1-expressing axon terminals, leading to disinhibition of hypocretinergic neurons and enhancing hypocretin innervation of target brain areas. This remodeling could be a consequence of leptin signaling impairment, since it was reversed by the systemic administration of leptin (Cristino et al., 2013). Therefore, in these pathological conditions, hypocretins could exacerbate obesity as a result of an increased hypocretin release in the hypothalamus, leading to hyperphagia and sleep disorders (Alpár and Harkany, 2013).
Another relevant integrative region in the control of appetite is the nucleus of the solitary tract (NTS) in the hindbrain, which regulates individual meal sizes and the intervals between meals (Valassi et al., 2008). Peripheral satiety signals are relayed to the NTS via vagal afferent neurons, whose cell bodies lie in the nodose ganglia. It has been recently reported that fasting-induced increase in CB1 immunoreactivity has been observed under standard food regime in the nodose ganglia (Cluny et al., 2013). In contrast, $\mathrm{OX}-1 \mathrm{R}$ immunoreactivity is modified by fasting only in rats exposed to high-fat diet, denoting a differential regulation of these neurotransmitter systems in this structure (Cluny et al., 2013). On the other hand, hypocretin-1 depolarizes NTS neurons through regulation of non-selective cationic and $\mathrm{K}+$ conductances in a PKC-dependent manner (Yang et al., 2003; Yang and Ferguson, 2003). It has ben also reported that CB1 receptor activation modulates NTS neuronal activity (Seagard et al., 2005; Endoh, 2006). However, it remains to be investigated whether these neurochemical effects in nodose ganglia and NTS are relevant in the control of feeding behavior, and if there exists an interplay between endocannabinoid and hypocretinergic mechanisms.

Endocannabinoid and hypocretinergic systems seem to play antagonistic roles in the peripheral control of energy balance. 


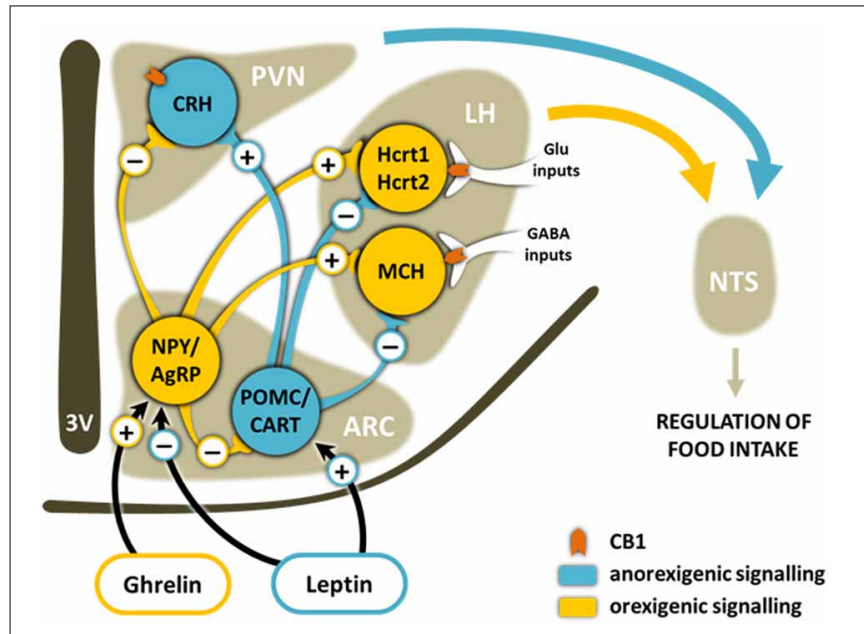

FIGURE 3 | Schematic representation of the main brain pathways involved in the homeostatic control of food intake. Ghrelin released during fasting from stomach and leptin from adipose tissue, among other mediators, bind to receptors on orexigenic and/or anorexigenic neurons in the ARC of the hypothalamus. This induces the release of either the orexigenic neuropeptides NPY and AgRP or the anorexigenic neuropeptides CART and the POMC-derived peptide $\alpha-\mathrm{MSH}$. These neuropeptides from the ARC travel along axons to secondary neurons in other areas of the hypothalamus such as the PVN and the $\mathrm{LH}$. The ultimate effects of these signaling cascades are changes in the sensation of hunger and satiety in the NTS. Hypocretinergic and $\mathrm{MCH}$ neurons are modulated differently by inhibitory or excitatory CB1-expressing inputs. ARC, arcuate nucleus; PVN, paraventricular nucleus; LH, lateral hypothalamus; NTS, nucleus of the tractus solitarius; $3 \mathrm{~V}$, third ventricle; NPY, neuropeptide $Y$; AgRP, Agouti-related peptide; CART, cocaine- and amphetamine-regulated transcript; $\mathrm{POMC}$, pro-opiomelanocortin; $\mathrm{MCH}$, melanin-concentrating hormone; $\mathrm{CRH}$, corticotropin-releasing hormone; Hcrt1, hypocretin-1; Hcrt2, hypocretin-2.

The reduction of body weight and fat mass exerted by CB1 antagonists in diet-induced obesity models is partially due to the counteraction of a peripheral stimulation of lipogenesis by endocannabinoids (Di Marzo and Matias, 2005). Moreover, chronic CB1 blockade improves peripheral metabolic parameters of obesity, including a reduction in plasma levels of insulin and leptin. In contrast, mice overproducing the hypocretin peptides exhibit resistance to high-fat diet-induced obesity at least in part by promoting energy expenditure (Tsuneki et al., 2010). These antiobesity metabolic effects have been demonstrated to be mediated by HcrtR2, which has been observed to improve leptin sensitivity (Funato et al., 2009). However, no studies have been yet published assessing whether endocannabinoid and hypocretinergic systems show a cross-modulation in their peripheral control of metabolic rates.

\section{REGULATION OF THE BRAIN REWARD SYSTEM}

Endocannabinoid and hypocretinergic systems are also involved in the regulation of the mesocorticolimbic rewarding system, a circuit responsible for the pleasurable feelings associated with natural rewards and the consumption of drugs of abuse. The major components of this reward circuit are the VTA, which contains the dopaminergic cell bodies, and its target areas, including the NAc, amygdala, frontal and limbic cortices (Wise, 2004).
CB1 and HcrtRs receptors are abundant in the brain reward circuitry and participate in the rewarding properties of natural rewards and also in those induced by different drugs of abuse (Maldonado et al., 2006). Acting as a retrograde messenger, endocannabinoids modulate the glutamatergic excitatory and GABAergic inhibitory synaptic inputs into the dopaminergic neurons of the VTA and the glutamate transmission in the NAc. Thus, the activation of $\mathrm{CB} 1$ receptors present on axon terminals of GABAergic neurons in the VTA inhibits GABA transmission, removing this inhibitory input on dopaminergic neurons (Riegel and Lupica, 2004). Glutamate synaptic transmission in the VTA and NAc, mainly from neurons of the PFC, is similarly modulated by the activation of CB1 receptors (Melis et al., 2004). The final effect of endocannabinoids on the modulation of dopaminergic activity, which depends on the functional balance between these GABAergic and glutamatergic inputs, is predominantly excitatory (Maldonado et al., 2006). On the other hand, hypocretins regulate reward seeking also by modulating VTA dopaminergic transmission. In agreement, intra-VTA infusion of hypocretin-1 and -2 increased dopamine release in NAc and PFC as measured by microdialysis or voltammetry (Vittoz et al., 2008; España et al., 2011). Hypocretins elicit their influence on VTA dopamine cell firing not only via direct depolarization of dopamine neurons (Korotkova et al., 2003), but also interacting with other neurotransmitters within the VTA, such as glutamate (Borgland et al., 2006). Thus, intra-VTA infusion of hypocretin-1 increased both glutamate and dopamine release, which was attenuated by the AMPA/NMDA antagonist kynurenic acid, suggesting that hypocretin has a profound influence on dopamine neurons by affecting glutamatergic activity (Wang et al., 2009). Hypocretin-1 enhanced glutamatergic synaptic strength on dopamine neurons in VTA slices (Borgland et al., 2006). In accordance, the control of this limbic structure by the PFC projections was improved by hypocretin-1 in rats (Mahler et al., 2013).

This considerable modulation of the reward circuit by endocannabinoid and hypocretinergic systems reveal their important role in the non-homeostatic control of food intake. CB1 receptor antagonists have been reported to reduce the conditioned place preference (CPP) for food (Chaperon et al., 1998), and the motivation for food in a progressive ratio schedule of food selfadministration in rats (Gallate and McGregor, 1999). According to this, null mutant $\mathrm{CB} 1$ mice show a reduced motivation to work for food compared to wild-type littermates (Sanchis-Segura et al., 2004). CB1 receptor blockade also decreases the reinforcing properties of chocolate and sweets (Maccioni et al., 2008). In addition, intra-NAc injections of anandamide enhance the reward associated with sweets (Mahler et al., 2007). Similarly, several data support a role for hypocretins in food-seeking and taking. Thus, chronic administration of the HcrtR1 antagonist SB334867 altered standard food self-administration in food-restricted mice (Sharf et al., 2010), although this effect was not observed in rats after acute administration of the HcrtR1 antagonist (Borgland et al., 2009). Indeed, it seems that hypocretinergic control of foodrelated reward is more relevant when it involves particularly palatable foods (Mahler et al., 2012). In agreement, SB334867 reduces both motivational and primary reinforcing effects in rats trained to self-administer high-fat food, both under food-restriction or 
satiation (Nair et al., 2008; Choi et al., 2010). So far, no studies have investigated if endocannabinoid and hypocretinergic systems have common mechanisms in the modulation of natural reward. However, it seems that both neurotransmitter systems regulate food intake especially when particularly palatable/or salient food is involved or higher effort is required to obtain this natural reinforcer.

Similarly, the addictive properties of several drugs of abuse are modulated by hypocretinergic and endocannabinoid systems. Hypocretin transmission regulates the primary reinforcing effects of opioids (Narita et al., 2006; Smith and Aston-Jones, 2012), nicotine (Hollander et al., 2008; LeSage et al., 2010) and alcohol (Lawrence et al., 2006; Moorman and Aston-Jones, 2009). However, the involvement of the hypocretin system in the rewarding properties of psychostimulants seems to be relevant only under conditions that require a high effort to obtain the drug (Boutrel et al., 2005; España et al., 2011). This distinct regulation could be due to differences among the mechanism of action by which these drugs of abuse alter the mesolimbic function (Plaza-Zabala et al., 2012). Opioids, nicotine and alcohol increase extracellular levels of dopamine in the NAc by enhancing dopaminergic firing rates in the VTA, whereas psychostimulants directly inhibit dopamine uptake in the NAc (Di Chiara et al., 2004). Thus, rewarding effects of drugs of abuse that depend on increased VTA dopaminergic activity may require hypocretinergic transmission, as the VTA appears to be an essential site of action for hypocretins to modulate these effects. In contrast, the mechanism of action of psychostimulants avoids this critical site of action of hypocretins. Intriguingly, a similar phenomenon occurs with the modulatory role of the endocannabinoid system on the primary rewarding effects of drugs of abuse. Thus, opioid (Navarro et al., 2001, 2004), cannabinoid (Maldonado et al., 2006), nicotine (Castañé et al., 2002; Cohen et al., 2002) and alcohol (Hungund et al., 2003; Wang et al., 2003) reinforcement depend on endocannabinoid signaling in the VTA, but primary rewarding effects of psychostimulants remain unaffected in the absence of CB1 receptors (Martin et al., 2000; Soria et al., 2005). However, the endocannabinoid system is important for maintaining psychostimulants seeking behavior when higher effort is required to obtain the drug, probably by the modulation of other mechanisms independent from release of dopamine in the NAc (Soria et al., 2005). It has been recently reported that CPP induced by chemical stimulation of the LH with the cholinergic agonist carbachol is regulated by HcrtR1 activation in the VTA. Thus, unilateral intra-VTA administration of the HcrtR1 antagonist SB334867 dose-dependently inhibited this behavioral response (Taslimi et al., 2011). Interestingly, intra-VTA administration of rimonabant also decreased CPP induced by LH-stimulation in a dose-dependent manner. Co-administration of effective doses of both HcrtR1 and CB1 antagonists into the VTA reduced CPP in a non-additive manner, suggesting that these receptors regulate this effect by a common mechanism (Taslimi et al., 2011). Nevertheless, future experiments showing the specific location of HcrtR1 and CB1 receptors within the VTA neurons will be necessary to better understand the interaction between the endocannabinoid and hypocretin systems in the regulation of the reward circuit.
A relevant but almost unexplored aspect of hypocretincannabinoid interplay is the role of the hypocretinergic system in the addictive properties of cannabinoids, whose recreational use has progressively increased in developed countries in the last decade (Murray et al., 2007). Therefore, the identification of new therapeutic targets to improve treatment outcomes for cannabis dependence is imperative considering that no effective pharmacotherapeutic approaches for this disorder are currently available. Although operant responding for self-infused THC has not been consistently reported in rodents, intravenous self-administration of the synthetic cannabinoid WIN55,212-2 has been observed in rats and mice (Fattore et al., 2001; Mendizábal et al., 2006). The reinforcing properties of cannabinoids have been related to their capability to enhance dopamine extracellular levels in the NAc shell (Fadda et al., 2006; Lecca et al., 2006), although other neurochemical systems have also been involved in cannabinoid reward, such as opioid, noradrenaline, serotonine, acetylcholine and adenosine systems (Maldonado et al., 2011).

Recently, the hypocretinergic system has also been reported to contribute to cannabinoid-induced reward. Indeed, genetic deletion or pharmacological blockade of HcrtR1 reduced the reinforcing effects of WIN55,212-2, as revealed by impaired intravenous self-administration of this synthetic cannabinoid in mice (Flores et al., 2013). In contrast, the HcrtR2 antagonist TCSOX229 had no effect in these behavioral responses. The enhancement in dopamine extracellular levels in the nucleus accumbens induced by THC was also blocked in mice lacking the HcrtR1, suggesting that cannabinoids require hypocretinergic transmission to induce dopamine release in the NAc. Moreover, contingent WIN55,212-2 self-administration, but not passive exposure to the cannabinoid, increased the percentage of hypocretin neurons expressing FosB/ $\Delta$ FosB in the $\mathrm{LH}$, revealing that this activation was mainly due to operant seeking for the reinforcing effects of this drug and not to its pharmacological responses (Flores et al., 2013). Cannabinoid-induced activation of hypocretin neurons reported in this study differs from previous electrophysiological data supporting that cannabinoids inhibit hypocretin neurons by CB1-mediated attenuation of glutamate release in these cells (Huang et al., 2007), but possible clarification of this divergence has recently emerged. As previously mentioned, a switch in CB1-mediated control of GABAergic and glutamatergic inputs is observed in obese mice (Cristino et al., 2013). It is thus reasonable that if this synaptic remodeling takes place in determined pathological conditions, such as obesity, the development of drug addiction might entail similar consequences by different mechanisms. However, this possibility still remains to be elucidated. Other recent evidence supports the relationship between hypocretins and cannabis dependence. It has been reported that hypocretin-1 expression in peripheral blood cells is modified in cannabis-dependent smokers when compared to nicotine-dependent smokers and non-smokers (Rotter et al., 2012). However, these data provide poor functional information, as peripheral hypocretin mRNA levels do not necessarily reflect the situation in the CNS. Moreover, it is likely that these differences are more related to peripheral actions of THC and not to the central effects involved in the development of dependence. 


\section{NOCICEPTION}

Analgesia is one of the main therapeutic targets of cannabinoids. CB1 receptors are highly expressed in pain transmission and modulation regions such as PAG, rostroventral medulla (RVM), spinal cord and primary afferent fibers (Hohmann and Suplita, 2006). Consistent with this anatomic location, several animal studies demonstrated that both endogenous and exogenous cannabinoids produce antinociceptive effects in different animal models mainly through the activation of CB1 receptors (Martin et al., 1993; Herzberg et al., 1997; Dogrul et al., 2002). Moreover, CB2 receptors have been reported to contribute to antinociception in some chronic pain models (Racz et al., 2008; La Porta et al., 2013). Cannabinoid-mediated antinociception takes places at peripheral, spinal and supraspinal levels. One of the best characterized mechanisms of pain modulation is the descending inhibitory pathway. This descending modulatory mechanism originates in the PAG, which activates neurons in the RVM, the main relay station between the PAG and spinal cord. RVM neurons send inhibitory projections to the dorsal horn of the spinal cord via dorsolateral funiculus (DLF) and modulate pain perception at the spinal level (Ren and Dubner, 2008). The demonstration that cannabinoid antinociceptive effects are diminished following surgical DLF lesion provides evidence that descending pain modulatory pathways play a crucial role in these responses (Lichtman and Martin, 1991). Thus, microinjection of the cannabinoid agonists HU210 and WIN55,212-2 into the PAG elicits antinociception mediated by $\mathrm{CB} 1$ receptor activation (Lichtman et al., 1996; Finn et al., 2003). This effect is the result of disinhibition of GABAergic output neurons in the PAG that leads to activation of descending inhibitory pain pathways (Vaughan et al., 2000). Similarly, local injection of CB1 agonists into RVM had antinociceptive effects due to presynaptic inhibition of GABAergic tone (Vaughan et al., 2000). Moreover, anandamide and 2-AG levels were increased in RVM in some models of chronic pain, presumably as an adaptive mechanism to counteract pain transmission (Petrosino et al., 2007).

Antinociceptive effects of hypocretins have been shown in several pain models (Chiou et al., 2010). Thus, hypocretin-1 administration by central or systemic route reduces the nociceptive responses in mice in response to thermal, mechanical and chemical stimuli (Mobarakeh et al., 2005). Hypocretin2 has also been reported to induce antinociceptive effects in some pain models, but with lower potency than hypocretin1 (Mobarakeh et al., 2005). Hypocretin-induced antinociception seems to be mainly mediated by HcrtR1, as revealed by using selective antagonists (Bingham et al., 2001). Hypocretincontaining fibers and HcrtRs are densely distributed in several regions of the CNS involved in the regulation of pain, including the PAG and spinal dorsal horn (Peyron et al., 1998; Marcus et al., 2001). Like cannabinoids, hypocretins appear to modulate pain perception at both spinal and supraspinal levels, but the mechanism of action remains unclear. The midbrain PAG is one of the possible supraspinal sites of hypocretin antinociception. Interestingly, PAG c-fos expression was elevated following central hypocretin administration (Date et al., 1999). In agreement, microinjection of hypocretin-1 into the PAG reduced hotplate nociceptive responses in mice (Lee and Chiou, 2009) and formalin-induced nociceptive behaviors in rats (Yamamoto et al., 2002). A recent study in PAG slices revealed that hypocretin1 induces inhibition of GABAergic transmission, producing an overall excitatory effect on evoked postsynaptic potentials and hence increasing PAG neuronal activity (Ho et al., 2011). This effect was blocked by the HcrtR1 antagonist SB334867, but not by the HcrtR2 antagonist TCSOX229. Moreover, the CB1 antagonist AM251 reversed the effect of hypocretin-1. Administration of U73122 and tetrahydrolipstatin, inhibitors of PLC and DAGL respectively, blocked the inhibition of GABAergic tone induced by hypocretin-1, while the inhibitor of the enzymatic degradation of 2-AG, URB602, enhanced this hypocretin effect. Therefore, hypocretin-1 may produce antinociception in part by activating postsynaptic HcrtR1 receptors and stimulating synthesis of 2-AG through a PLC-DAGL enzymatic cascade, culminating in retrograde inhibition of GABA release in the PAG. The in vivo existence of such analgesic mechanism was confirmed by systemic administration of SB334867 and AM251 after intra-PAG microinjection of hypocretin-1, which almost fully reversed the antinociceptive responses in the hot-plate test in rats (Ho et al., 2011). Importantly, this 2-AG-mediated antinociception induced by hypocretin signaling may contribute to stress-induced analgesia, since hypocretins have been reported to modulate this response to stress (Watanabe et al., 2005; Xie et al., 2008) and endocannabinoids within the PAG are also believed to be involved in this effect (Hohmann and Suplita, 2006). Therefore, under stressful conditions, activation of HcrtR1 may lead to PAG stimulation and produce analgesia through 2-AG via the CB1-PLC-DAGL cascade.

Both endocannabinoid and hypocretinergic systems exert also antinociceptive effects at the spinal (Drew et al., 2000; Grudt et al., 2002) and peripheral levels (Millns et al., 2001; Yan et al., 2008), but no data are available regarding a possible contribution of endocannabinoids in spinal or peripheral hypocretin-induced analgesia. Moreover, the possible modulation of cannabinoidinduced antinociception by hypocretins has not been studied yet.

\section{SLEEP/WAKE CYCLE}

Several data indicates that the hypocretinergic system is involved in the regulation of sleep-wake cycle. Thus, hypocretin neurons fire at maximal rate in wakefulness and remain silent in rapid eye movement (REM) sleep (Lee et al., 2005). Likewise, pharmacological stimulation of the hypocretinergic system increases wakefulness and reduces REM sleep (Akanmu and Honda, 2005). Accordingly, the dysfunction of this system is linked to narcolepsy, as revealed in dogs with mutated HcrtR2 gene and mice lacking hypocretins or HcrtR2 (Lin et al., 1999; Willie et al., 2003). On the other hand, endocannabinoids are also involved in sleep regulation and have been shown to be strong sleep-inducers (Cravatt et al., 1995). Besides, systemic administration of rimonabant increases wakefulness and decreases REM sleep in rats (Santucci et al., 1996), whereas acute (Murillo-Rodríguez et al., 2001), subchronic (Herrera-Solís et al., 2010) and intrahippocampal (Rueda-Orozco et al., 2010) administration of anandamide has the opposite effect.

Few studies have investigated the possible mechanisms shared by the hypocretinergic and endocannabinoid systems in the 
regulation of sleep and wakefulness. The finding that cannabinoid signaling leads to hyperpolarization of hypocretin neurons and depolarization of $\mathrm{MCH}$ neurons in in vitro preparations (Huang et al., 2007) encouraged the idea that endocannabinoids could interact with these hypothalamic neurons to regulate sleep. Indeed, intra-hypothalamic administration of 2-AG increases REM sleep in rats through $\mathrm{CB1}$ receptor and $\mathrm{MCH}$ signaling, since 2-AG slightly decreased c-fos expression in hypocretin neurons and activated MCH neurons (Pérez-Morales et al., 2013). Endocannabinoid and hypocretinergic systems could be involved in the modulation of sleep/wake cycle by acting in dorsal raphe nucleus (DRN) serotonergic neurons, closely linked to REM sleep and arousal. Thus, these neurons discharge at a high frequency during waking, at a lower rate during non-REM sleep and become silent during REM sleep (McGinty and Harper, 1976; Portas et al., 1996). Activation of HcrtRs increases activity of DRN serotonergic neurons (Brown et al., 2001; Liu et al., 2002). However, an electrophysiological study performed in rat DRN slices has reported that hypocretin-2 also inhibits glutamatergic transmission to serotonergic neurons of the DRN via retrograde endocannabinoid messengers (Haj-Dahmane and Shen, 2005). Although the functional implications of this retrograde synaptic modulation are not clear, the authors propose that it could prevent excessive excitation of DRN serotonergic neurons to provide a homeostatic control, contributing to the stable firing activity of these arousal-related neurons. Therefore, the loss of the hypocretin signal could lead to the disorganized activity and fragmented wakefulness observed in narcolepsy (Haj-Dahmane and Shen, 2005). However, further studies should be carried out to clarify the relevance of the possible interactions between cannabinoid and hypocretinergic systems in sleep modulation.

\section{CONCLUDING REMARKS}

The existence of a cross-talk between the hypocretinergic and endocannabinoid systems is strongly supported by their partially overlapping anatomical distribution and common role in several physiological and pathological processes. However, little is known about the mechanisms underlying this interaction. The formation of heteromers between HcrtR1 and CB1 receptors has been demonstrated in vitro, which alters the cellular localization and downstream signaling of both receptors. However, the biological significance of these heteromers remains unknown, and further studies are needed to verify whether the two receptors are expressed on the same target neurons and if they form heteromers in vivo. In this regard, better tools should be developed to determine the specific location of HcrtRs due to the cross-reactivity problems of the currently available antibodies (Kukkonen, 2012). On the other hand, hypocretin signaling has been reported to stimulate the synthesis of 2-AG leading to retrograde inhibition, which suggests that endocannabinoids might contribute to several hypocretin effects. Recent evidence denotes that this endocannabinoid-mediated retrograde inhibition is present in diverse brain regions in vivo, being of special relevance in the regulation of the analgesic effects induced by hypocretins. Interesting data also point to a collaboration of endocannabinoid and hypocretinergic systems in the central control of food intake and obesity. The hypocretinergic transmission is overstimulated in this pathological condition, and HcrtR antagonists might be useful in the control of appetite and other disorders associated with obesity, such as anxiety and sleep deregulations. However, the apparent antiobesity role of HcrtR2 in the peripheral control of energy balance should be taken into account and would possibly require the use of selective HcrtR1 antagonists for this specific purpose. Blockade of HcrtR1 signaling has demonstrated also its therapeutic potential against cannabinoid dependence by interfering with the rewarding effects of this drug. Nevertheless, the variety of hypocretin and endocannabinoid signaling implies that their manipulation to regulate a specific physiological process would probably produce several side effects. To avoid this problem, efforts should be focused on the development of selective agonists/antagonists for the different receptors and/or with site specific activity. Some authors defend that diverse GPCR heteromers are diseasespecific and/or exhibit unique tissue specificity (Gomes et al., 2013). If this would be the case of CB1-HcrtR1 heteromers, they would serve as ideal drug targets with potentially lesser side effects that the single receptors. Although research about the cannabinoid-hypocretinergic interplay has only taken the first steps, future investigation in this field will lead to a better understanding of the therapeutic potential of this interesting interaction.

\section{ACKNOWLEDGMENTS}

This work was supported by the Instituto de Salud Carlos III grants, \#PI07/0559, \#PI10/00316 and \#RD06/001/001 (RTARETICS), by the Spanish Ministry of Science and Technology, Consolider-C \#SAF2007-64062 and \#SAF2011-29864, the Catalan Government (SGR2009-00731), and by the Catalan Institution for Research and Advanced Studies (ICREA Academia program). África Flores is recipient of a predoctoral fellowship from the Spanish Ministry of Education.

\section{REFERENCES}

Akanmu, M. A., and Honda, K. (2005). Selective stimulation of orexin receptor type 2 promotes wakefulness in freely behaving rats. Brain Res. 1048, 138-145. doi: 10.1016/j.brainres.2005.04.064

Alpár, A., and Harkany, T. (2013). Orexin neurons use endocannabinoids to break obesity-induced inhibition. Proc. Natl. Acad. Sci. U.S.A. 110, 9625-9626. doi: 10.1073/pnas. 1307389110

Ammoun, S., Holmqvist, T., Shariatmadari, R., Oonk, H. B., Detheux, M., Parmentier, M. et al. (2003). Distinct recognition of OX1 and OX2 receptors by orexin peptides. J. Pharmacol. Exp. Ther. 305, 507-514. doi: 10.1124/jpet.102.048025

Ammoun, S., Johansson, L., Ekholm, M. E., Holmqvist, T., Danis, A. S., Korhonen, L., et al. (2006b). OX1 orexin receptors activate extracellular signal-regulated kinase in Chinese hamster ovary cells via multiple mechanisms: the role of $\mathrm{Ca} 2+$ influx in OX1 receptor signaling. Mol. Endocrinol. 20, 80-99. doi: 10.1210/me.2004-0389

Ammoun, S., Lindholm, D., Wootz, H., Akerman, K. E., and Kukkonen, J. P. (2006a). G-protein-coupled OX1 orexin/hcrtr-1 hypocretin receptors induce caspase-dependent and -independent cell death through p38 mitogen-/stress-activated protein kinase. J. Biol. Chem. 281, 834-842. doi: 10.1074/jbc.M508603200

Aston-Jones, G., Smith, R. J., Sartor, G. C., Moorman, D. E., Massi, L., Tahsili-Fahadan, P. et al. (2010). Lateral hypothalamic orexin/hypocretin neurons: a role in reward-seeking and addiction. Brain Res. 1314, 74-90. doi: 10.1016/j.brainres.2009.09.106 
Berthoud, H. R. (2007). Interactions between the "cognitive" and "metabolic" brain in the control of food intake. Physiol Behav. 91, 486-498. doi: 10.1016/j.physbeh.2006.12.016

Bingham, S., Davey, P. T., Babbs, A. J., Irving, E. A., Sammons, M. J., Wyles, M., et al. (2001). Orexin-A, an hypothalamic peptide with analgesic properties. Pain 92, 81-90. doi: 10.1016/S0304-3959(00)00470-X

Borgland, S. L., Chang, S. J., Bowers, M. S., Thompson, J. L., Vittoz, N., Floresco, S. B., et al. (2009). Orexin A/hypocretin-1 selectively promotes motivation for positive reinforcers. J. Neurosci. 29, 11215-11225. doi: 10.1523/JNEUROSCI.609608.2009

Borgland, S. L., Taha, S. A., Sarti, F., Fields, H. L., and Bonci, A. (2006). Orexin $A$ in the VTA is critical for the induction of synaptic plasticity and behavioral sensitization to cocaine. Neuron 49, 589-601. doi: 10.1016/j.neuron.2006. 01.016

Bouaboula, M., Perrachon, S., Milligan, L., Canat, X., Rinaldi-Carmona, M., Portier, M., et al. (1997). A selective inverse agonist for central cannabinoid receptor inhibits mitogen-activated protein kinase activation stimulated by insulin or insulin-like growth factor 1. Evidence for a new model of receptor/ligand interactions. J Biol. Chem. 272, 22330-22339. doi: 10.1074/jbc.272.35.22330

Bouaboula, M., Poinot-Chazel, C., Bourrié, B., Canat, X., Calandra, B., RinaldiCarmona, M., et al. (1995). Activation of mitogen-activated protein kinases by stimulation of the central cannabinoid receptor CB1. Biochem. J. 312, 637-641.

Boutrel, B., Kenny, P. J., Specio, S. E., Martin-Fardon, R., Markou, A., Koob, G. F., et al. (2005). Role for hypocretin in mediating stress-induced reinstatement of cocaine-seeking behavior. Proc. Natl. Acad. Sci. U.S.A. 102, 19168-19173. doi: 10.1073/pnas.0507480102

Brown, R. E., Sergeeva, O., Eriksson, K. S., and Haas, H. L. (2001). Orexin A excites serotonergic neurons in the dorsal raphe nucleus of the rat. Neuropharmacology 40, 457-459. doi: 10.1016/S0028-3908(00)00178-7

Burdakov, D., Liss, B., and Ashcroft, F. M. (2003). Orexin excites GABAergic neurons of the arcuate nucleus by activating the sodium-calcium exchanger. $J$. Neurosci. 23, 4951-4957.

Carriba, P., Ortiz, O., Patkar, K., Justinova, Z., Stroik, J., Themann, A. et al. (2007). Striatal adenosine A2A and cannabinoid CB1 receptors form functional heteromeric complexes that mediate the motor effects of cannabinoids. Neuropsychopharmacology 32, 2249-2259. doi: 10.1038/sj.npp. 1301375

Cason, A. M., Smith, R. J., Tahsili-Fahadan, P., Moorman, D. E., Sartor, G. C., and Aston-Jones, G. (2010). Role of orexin/hypocretin in reward-seeking and addiction: implications for obesity. Physiol Behav. 100, 419-428. doi: 10.1016/j.physbeh.2010.03.009

Castañé, A., Valjent, E., Ledent, C., Parmentier, M., Maldonado, R., and Valverde, O. (2002). Lack of CB1 cannabinoid receptors modifies nicotine behavioural responses, but not nicotine abstinence. Neuropharmacology 43, 857-867. doi: 10.1016/S0028-3908(02)00118-1

Chaperon, F., Soubrié, P., Puech, A. J., and Thiébot, M. H. (1998). Involvement of central cannabinoid (CB1) receptors in the establishment of place conditioning in rats. Psychopharmacology (Berl.) 135, 324-332. doi: 10.1007/s002130 050518

Chiou, L. C., Lee, H. J., Ho, Y. C., Chen, S. P., Liao, Y. Y., Ma, C. H., et al. (2010). Orexins/hypocretins: pain regulation and cellular actions. Curr. Pharm. Des. 16, 3089-3100. doi: 10.2174/138161210793292483

Choi, D. L., Davis, J. F., Fitzgerald, M. E., and Benoit, S. C. (2010). The role of orexin-A in food motivation, reward-based feeding behavior and food-induced neuronal activation in rats. Neuroscience 167, 11-20. doi: 10.1016/j.neuroscience.2010.02.002

Cluny, N. L., Baraboi, E. D., Mackie, K., Burdyga, G., Richard, D., Dockray, G. J., et al. (2013). High fat diet and body weight have different effects on cannabinoid CB1 receptor expression in rat nodose ganglia. Auton. Neurosci. 179, 122-130. doi: 10.1016/j.autneu.2013.09.015

Cohen, C., Perrault, G., Voltz, C., Steinberg, R., and Soubrié, P. (2002). SR141716, a central cannabinoid $(\mathrm{CB}(1))$ receptor antagonist, blocks the motivational and dopamine-releasing effects of nicotine in rats. Behav Pharmacol. 13, 451-463. doi: 10.1097/00008877-200209000-00018

Colombo, G., Agabio, R., Diaz, G., Lobina, C., Reali, R., and Gessa, G. L. (1998). Appetite suppression and weight loss after the cannabinoid antagonist SR 141716. Life Sci. 63, PL113-117. doi: 10.1016/S0024-3205(98) 00322-1
Cota, D., Marsicano, G., Lutz, B., Vicennati, V., Stalla, G. K., Pasquali, R., et al. (2003). Endogenous cannabinoid system as a modulator of food intake. Int. J. Obes. Relat. Metab. Disord. 27, 289-301. doi: 10.1038/sj.ijo. 0802250

Cravatt, B. F., Prospero-Garcia, O., Siuzdak, G., Gilula, N. B., Henriksen, S. J., Boger, D. L., et al. (1995). Chemical characterization of a family of brain lipids that induce sleep. Science 268, 1506-1509. doi: 10.1126/science. 7770779

Crespo, I., Gómez de Heras, R., Rodríguez de Fonseca, F., and Navarro, M. (2008). Pretreatment with subeffective doses of Rimonabant attenuates orexigenic actions of orexin A-hypocretin 1. Neuropharmacology 54, 219-225. doi: 10.1016/j.neuropharm.2007.05.027

Cristino, L., Busetto, G., Imperatore, R., Ferrandino, I., Palomba, L., Silvestri, C., et al. (2013). Obesity-driven synaptic remodeling affects endocannabinoid control of orexinergic neurons. Proc. Natl. Acad. Sci. U.S.A. 110, E2229-E2238. doi: 10.1073/pnas. 1219485110

Date, Y., Ueta, Y., Yamashita, H., Yamaguchi, H., Matsukura, S., Kangawa, K., et al. (1999). Orexins, orexigenic hypothalamic peptides, interact with autonomic, neuroendocrine and neuroregulatory systems. Proc. Natl. Acad. Sci. U.S.A. 96, 748-753. doi: 10.1073/pnas.96.2.748

Davis, S. F., Williams, K. W., Xu, W., Glatzer, N. R., and Smith, B. N. (2003). Selective enhancement of synaptic inhibition by hypocretin (orexin) in rat vagal motor neurons: implications for autonomic regulation. J. Neurosci. 23, 3844-3854.

Deadwyler, S. A., Hampson, R. E., Mu, J., Whyte, A., and Childers, S. (1995). Cannabinoids modulate voltage sensitive potassium A-current in hippocampal neurons via a cAMP-dependent process. J. Pharmacol. Exp. Ther. 273, 734-743.

de Lecea, L., Kilduff, T. S., Peyron, C., Gao, X., Foye, P. E., Danielson, P. E. et al. (1998). The hypocretins: hypothalamus-specific peptides with neuroexcitatory activity. Proc. Natl. Acad. Sci. U.S.A. 95, 322-327. doi: 10.1073/pnas.95. 1.322

Demuth, D. G., and Molleman, A. (2006). Cannabinoid signalling. Life Sci. 78, 549-563. doi: 10.1016/j.lfs.2005.05.055

Derkinderen, P., Ledent, C., Parmentier, M., and Girault, J. A. (2001). Cannabinoids activate p38 mitogen-activated protein kinases through CB1 receptors in hippocampus. J. Neurochem. 77, 957-960. doi: 10.1046/j.1471-4159.2001. 00333.x

Devane, W. A., Hanus, L., Breuer, A., Pertwee, R. G., Stevenson, L. A., Griffin, G., et al. (1992). Isolation and structure of a brain constituent that binds to the cannabinoid receptor. Science 258, 1946-1949. doi: 10.1126/science. 1470919

Di Chiara, G., Bassareo, V., Fenu, S., De Luca, M. A., Spina, L., Cadoni, C., et al. (2004). Dopamine and drug addiction: the nucleus accumbens shell connection. Neuropharmacology 47(Suppl. 1), 227-241. doi: 10.1016/j.neuropharm.2004.06.032

Di Marzo, V. (2009). The endocannabinoid system: its general strategy of action, tools for its pharmacological manipulation and potential therapeutic exploitation. Pharmacol Res. 60, 77-84. doi: 10.1016/j.phrs.2009. 02.010

Di Marzo, V., Goparaju, S. K., Wang, L., Liu, J., Bátkai, S., Járai, Z., et al. (2001). Leptin-regulated endocannabinoids are involved in maintaining food intake. Nature 410, 822-825. doi: 10.1038/35071088

Di Marzo, V., and Matias, I. (2005). Endocannabinoid control of food intake and energy balance. Nat. Neurosci. 8, 585-589. doi: 10.1038/nn1457

Dogrul, A., Gardell, L. R., Ma, S., Ossipov, M. H., Porreca, F., and Lai, J. (2002). "Knock-down" of spinal CB1 receptors produces abnormal pain and elevates spinal dynorphin content in mice. Pain 100, 203-209. doi: 10.1016/S03043959(02)00302-0

Drew, L. J., Harris, J., Millns, P. J., Kendall, D. A., and Chapman, V. (2000). Activation of spinal cannabinoid 1 receptors inhibits C-fibre driven hyperexcitable neuronal responses and increases [35S]GTPgammaS binding in the dorsal horn of the spinal cord of noninflamed and inflamed rats. Eur. J. Neurosci. 12, 2079-2086. doi: 10.1046/j.1460-9568.2000. 00101.x

Elias, C. F., Saper, C. B., Maratos-Flier, E., Tritos, N. A., Lee, C., Kelly, J., et al. (1998). Chemically defined projections linking the mediobasal hypothalamus and the lateral hypothalamic area. J. Comp. Neurol. 402, 442-459. doi: 10.1002/(SICI)1096-9861(19981228)402:4<442::AID-CNE2>3.3.CO;2-I 
Ellis, J., Pediani, J. D., Canals, M., Milasta, S., and Milligan, G. (2006). Orexin-1 receptor-cannabinoid $\mathrm{CB} 1$ receptor heterodimerization results in both liganddependent and -independent coordinated alterations of receptor localization and function. J. Biol. Chem. 281, 38812-38824. doi: 10.1074/jbc.M602494200

Endoh, T. (2006). Pharmacological characterization of inhibitory effects of postsynaptic opioid and cannabinoid receptors on calcium currents in neonatal rat nucleus tractus solitarius. Br. J. Pharmacol. 147, 391-401. doi: 10.1038/sj.bjp.0706623

Eriksson, K. S., Sergeeva, O., Brown, R. E., and Haas, H. L. (2001). Orexin/hypocretin excites the histaminergic neurons of the tuberomammillary nucleus. J. Neurosci. 21, 9273-9279.

Eriksson, K. S., Sergeeva, O. A., Haas, H. L., and Selbach, O. (2010). Orexins/hypocretins and aminergic systems. Acta Physiol. (Oxf.) 198, 263-275. doi: 10.1111/j.1748-1716.2009.02015.x

España, R. A., Melchior, J. R., Roberts, D. C., and Jones, S. R. (2011). Hypocretin 1/orexin $\mathrm{A}$ in the ventral tegmental area enhances dopamine responses to cocaine and promotes cocaine self-administration. Psychopharmacology (Berl.) 214, 415-426. doi: 10.1007/s00213-010-2048-8

Fadda, P., Scherma, M., Spano, M. S., Salis, P., Melis, V., Fattore, L., et al. (2006). Cannabinoid self-administration increases dopamine release in the nucleus accumbens. Neuroreport 17, 1629-1632. doi: 10.1097/01.wnr.00002 36853.40221.8e

Fattore, L., Cossu, G., Martellotta, C. M., and Fratta, W. (2001). Intravenous selfadministration of the cannabinoid CB1 receptor agonist WIN 55,212-2 in rats. Psychopharmacology (Berl.) 156, 410-416. doi: 10.1007/s002130100734

Fernández-Ruiz, J., Hernández, M., and Ramos, J. A. (2010). Cannabinoiddopamine interaction in the pathophysiology and treatment of CNS disorders. CNS Neurosci. Ther. 16, e72-e91. doi: 10.1111/j.1755-5949.2010. 00144.x

Ferré, S., Lluís, C., Justinova, Z., Quiroz, C., Orru, M., Navarro, G. et al. (2009). Adenosine-cannabinoid receptor interactions. Implications for striatal function. Br. J. Pharmacol. 160, 443-453. doi: 10.1111/j.1476-5381.2010. 00723.x

Finn, D. P., Jhaveri, M. D., Beckett, S. R., Roe, C. H., Kendall, D. A., Marsden, C. A., et al. (2003). Effects of direct periaqueductal gray administration of a cannabinoid receptor agonist on nociceptive and aversive responses in rats. Neuropharmacology 45, 594-604. doi: 10.1016/S0028-3908(03) 00235-1

Flores, Á., Maldonado, R., and Berrendero, F. (2013). The hypocretin/orexin receptor-1 as a novel target to modulate cannabinoid reward. Biol. Psychiatry. doi: 10.1016/j.biopsych.2013.06.012. [Epub ahead of print].

Funato, H., Tsai, A. L., Willie, J. T., Kisanuki, Y., Williams, S. C., Sakurai, T., et al. (2009). Enhanced orexin receptor-2 signaling prevents dietinduced obesity and improves leptin sensitivity. Cell Metab. 9, 64-76. doi: 10.1016/j.cmet.2008.10.010

Gallate, J. E., and McGregor, I. S. (1999). The motivation for beer in rats: effects of ritanserin, naloxone and SR 141716. Psychopharmacology (Berl.) 142, 302-308. doi: $10.1007 / \mathrm{s} 002130050893$

Galve-Roperh, I., Rueda, D., Gómez del Pulgar, T., Velasco, G., and Guzmán, M. (2002). Mechanism of extracellular signal-regulated kinase activation by the $\mathrm{CB}(1)$ cannabinoid receptor. Mol. Pharmacol. 62, 1385-1392. doi: 10.1124/mol.62.6.1385

Girault, E. M., Yi, C. X., Fliers, E., and Kalsbeek, A. (2012). Orexins, feeding, and energy balance. Prog. Brain Res. 198, 47-64. doi: 10.1016/B978-0-444-594891.00005-7

Glass, M., and Felder, C. C. (1997). Concurrent stimulation of cannabinoid CB1 and dopamine D2 receptors augments cAMP accumulation in striatal neurons: evidence for a Gs linkage to the CB1 receptor. J. Neurosci. 17, 5327-5333.

Gomes, I., Fujita, W., Chandrakala, M. V., and Devi, L. A. (2013). Disease-specific heteromerization of G-protein-coupled receptors that target drugs of abuse. Prog. Mol. Biol. Transl. Sci. 117, 207-265. doi: 10.1016/B978-0-12-3869319.00009-X

Gómez del Pulgar, T., Velasco, G., and Guzmán, M. (2000). The CB1 cannabinoid receptor is coupled to the activation of protein kinase B/Akt. Biochem. J. 347, 369-373. doi: 10.1042/0264-6021:3470369

Gong, J. P., Onaivi, E. S., Ishiguro, H., Liu, Q. R., Tagliaferro, P. A., Brusco, A., et al. (2006). Cannabinoid CB2 receptors: immunohistochemical localization in rat brain. Brain Res. 1071, 10-23. doi: 10.1016/j.brainres.2005. 11.035
Gorojankina, T., Grébert, D., Salesse, R., Tanfin, Z., and Caillol, M. (2007). Study of orexins signal transduction pathways in rat olfactory mucosa and in olfactory sensory neurons-derived cell line Odora: multiple orexin signalling pathways. Regul. Pept. 141, 73-85. doi: 10.1016/j.regpep.2006.12.012

Grudt, T. J., van den Pol, A. N., and Perl, ER. (2002). Hypocretin-2 (orexin-B) modulation of superficial dorsal horn activity in rat. J. Physiol. 538, 517-525. doi: 10.1113/jphysiol.2001.013120

Haj-Dahmane, S., and Shen, R. Y. (2005). The wake-promoting peptide orexin-B inhibits glutamatergic transmission to dorsal raphe nucleus serotonin neurons through retrograde endocannabinoid signaling. J. Neurosci. 25, 896-905. doi: 10.1523/JNEUROSCI.3258-04.2005

Hall, W., and Degenhardt, L. (2009). Adverse health effects of non-medical cannabis use. Lancet 374, 1383-1391. doi: 10.1016/S0140-6736(09) 61037-0

Hampson, R. E., Evans, G. J., Mu, J., Zhuang, S. Y., King, V. C., Childers, S. R, et al. (1995). Role of cyclic AMP dependent protein kinase in cannabinoid receptor modulation of potassium "A-current" in cultured rat hippocampal neurons. Life Sci. 56, 2081-2088. doi: 10.1016/0024-3205(95)00192-9

Hanus, L., Abu-Lafi, S., Fride, E., Breuer, A., Vogel, Z., Shalev, D. E., et al. (2001). 2-arachidonyl glyceryl ether, an endogenous agonist of the cannabinoid CB1 receptor. Proc. Natl. Acad. Sci. U.S.A. 98, 3662-3665. doi: 10.1073/pnas.0610 29898

Häring, M., Guggenhuber, S., and Lutz, B. (2012). Neuronal populations mediating the effects of endocannabinoids on stress and emotionality. Neuroscience 204, 145-158. doi: 10.1016/j.neuroscience.2011.12.035

Haynes, A. C., Jackson, B., Chapman, H., Tadayyon, M., Johns, A., Porter, R. A. et al. (2000). A selective orexin-1 receptor antagonist reduces food consumption in male and female rats. Regul. Pept. 96, 45-51. doi: 10.1016/S01670115(00)00199-3

Herkenham, M., Lynn, A. B., Little, M. D., Johnson, M. R., Melvin, L. S., de Costa, B. R., et al. (1990). Cannabinoid receptor localization in brain. Proc. Natl. Acad. Sci. U.S.A. 87, 1932-1936. doi: 10.1073/pnas.87.5.1932

Herrera-Solís, A., Vásquez, K. G., and Prospéro-García, O. (2010). Acute and subchronic administration of anandamide or oleamide increases REM sleep in rats. Pharmacol. Biochem. Behav. 95, 106-112. doi: 10.1016/j.pbb.2009. 12.014

Hervieu, G. J., Cluderay, J. E., Harrison, D. C., Roberts, J. C., and Leslie, R. A. (2001). Gene expression and protein distribution of the orexin-1 receptor in the rat brain and spinal cord. Neuroscience 103, 777-797. doi: 10.1016/S03064522(01)00033-1

Herzberg, U., Eliav, E., Bennett, G. J., and Kopin, I. J. (1997). The analgesic effects of $\mathrm{R}(+)$-WIN 55,212-2 mesylate, a high affinity cannabinoid agonist, in a rat model of neuropathic pain. Neurosci. Lett. 221, 157-160. doi: 10.1016/S03043940(96)13308-5

Hilairet, S., Bouaboula, M., Carrière, D., Le Fur, G., and Casellas, P. (2003). Hypersensitization of the Orexin 1 receptor by the $\mathrm{CB} 1$ receptor: evidence for cross-talk blocked by the specific CB1 antagonist, SR141716. J. Biol Chem. 278, 23731-23737. doi: 10.1074/jbc.M212369200

Ho, Y. C., Lee, H. J., Tung, L. W., Liao, Y. Y., Fu, S. Y., Teng, S. F., et al. (2011). Activation of orexin 1 receptors in the periaqueductal gray of male rats leads to antinociception via retrograde endocannabinoid (2arachidonoylglycerol)-induced disinhibition. J. Neurosci. 31, 14600-14610. doi: 10.1523/JNEUROSCI.2671-11.2011

Hohmann, A. G., and Suplita, R. L. 2nd. (2006). Endocannabinoid mechanisms of pain modulation. AAPS J. 8, E693-E708. doi: 10.1208/aapsj080479

Hollander, J. A., Lu, Q., Cameron, M. D., Kamenecka, T. M., and Kenny, P. J. (2008). Insular hypocretin transmission regulates nicotine reward. Proc. Natl. Acad. Sci. U.S.A. 105, 19480-19485. doi: 10.1073/pnas.0808023105

Holmqvist, T., Johansson, L., Ostman, M., Ammoun, S., Akerman, K. E., and Kukkonen, J. P. (2005). OX1 orexin receptors couple to adenylyl cyclase regulation via multiple mechanisms. J. Biol. Chem. 280, 6570-6579. doi: 10.1074/jbc.M407397200

Howlett, A. C., Barth, F., Bonner, T. I., Cabral, G., Casellas, P., Devane, W. A., et al. (2002). International Union of Pharmacology. XXVII. Classification of cannabinoid receptors. Pharmacol. Rev. 54, 161-202. doi: 10.1124/pr.54. 2.161

Howlett, A. C., Qualy, J. M., and Khachatrian, L. L. (1986). Involvement of Gi in the inhibition of adenylate cyclase by cannabimimetic drugs. Mol. Pharmacol. 29, 307-313. 
Howlett, A. C., Reggio, P. H., Childers, S. R., Hampson, R. E., Ulloa, N. M., and Deutsch, D. G. (2011). Endocannabinoid tone versus constitutive activity of cannabinoid receptors. Br. J. Pharmacol. 163, 1329-1343. doi: 10.1111/j.14765381.2011.01364.x

Huang, H., Acuna-Goycolea, C., Li, Y., Cheng, H. M., Obrietan, K., and van den Pol, A. N. (2007). Cannabinoids excite hypothalamic melanin-concentrating hormone but inhibit hypocretin/orexin neurons: implications for cannabinoid actions on food intake and cognitive arousal. J. Neurosci. 27, 4870-4881. doi: 10.1523/JNEUROSCI.0732-07.2007

Hungund, B. L., Szakall, I., Adam, A., Basavarajappa, B. S., and Vadasz, C. (2003). Cannabinoid $\mathrm{CB} 1$ receptor knockout mice exhibit markedly reduced voluntary alcohol consumption and lack alcohol-induced dopamine release in the nucleus accumbens. J. Neurochem. 84, 698-704. doi: 10.1046/j.1471-4159.2003. 01576.x

Hwang, L. L., Chen, C. T., and Dun, N. J. (2001). Mechanisms of orexin-induced depolarizations in rat dorsal motor nucleus of vagus neurones in vitro. J. Physiol. 537, 511-520. doi: 10.1111/j.1469-7793.2001.00511.x

Ishibashi, M., Takano, S., Yanagida, H., Takatsuna, M., Nakajima, K., Oomura, Y., et al. (2005). Effects of orexins/hypocretins on neuronal activity in the paraventricular nucleus of the thalamus in rats in vitro. Peptides 26, 471-481. doi: 10.1016/j.peptides.2004.10.014

Jäntti, M. H., Putula, J., Turunen, P. M., Näsman, J., Reijonen, S., Lindqvist, C., et al. (2013). Autocrine endocannabinoid signaling through CB1 receptors potentiates OX1 orexin receptor signaling. Mol. Pharmacol. 83, 621-632. doi: 10.1124/mol.112.080523

Jarrahian, A., Watts, V. J., and Barker, E. L. (2004). D2 dopamine receptors modulate Galpha-subunit coupling of the CB1 cannabinoid receptor. J. Pharmacol. Exp. Ther. 308, 880-886. doi: 10.1124/jpet.103.057620

Kano, M., Ohno-Shosaku, T., Hashimotodani, Y., Uchigashima, M., and Watanabe, M. (2009). Endocannabinoid-mediated control of synaptic transmission. Physiol. Rev. 89, 309-380. doi: 10.1152/physrev.00019.2008

Kirkham, T. C., Williams, C. M., Fezza, F., and Di Marzo, V. (2002). Endocannabinoid levels in rat limbic forebrain and hypothalamus in relation to fasting, feeding and satiation: stimulation of eating by 2 arachidonoyl glycerol. Br. J. Pharmacol. 36, 550-557. doi: 10.1038/sj.bjp. 0704767

Korotkova, T. M., Sergeeva, O. A., Eriksson, K. S., Haas, H. L., and Brown, R. E. (2003). Excitation of ventral tegmental area dopaminergic and nondopaminergic neurons by orexins/hypocretins. J. Neurosci. 23, 7-11.

Kukkonen, J. P. (2011). A ménage à trois made in heaven: G-proteincoupled receptors, lipids and TRP channels. Cell Calcium. 50, 9-26. doi: 10.1016/j.ceca.2011.04.005

Kukkonen, J. P. (2012). Physiology of the orexinergic/hypocretinergic system: a revisit in 2012. Am. J. Physiol. Cell Physiol. 304, C2-C32. doi: 10.1152/ajpcell.00227.2012

Kukkonen, J. P., and Akerman, K. E. (2001). Orexin receptors couple to Ca2+ channels different from store-operated Ca2+ channels. Neuroreport 12, 2017-2020. doi: 10.1097/00001756-200107030-00046

Kukkonen, J. P., Holmqvist, T., Ammoun, S., and Akerman, K. E. (2002). Functions of the orexinergic/hypocretinergic system. Am. J. Physiol. Cell Physiol. 283, C1567-C1591. doi: 10.1152/ajpcell.00055.2002

Kukkonen, J. P., and Leonard, C. S. (2013). Orexin/hypocretin receptor signalling cascades. Br. J. Pharmacol. doi: 10.1111/bph.12324. [Epub ahead of print].

La Porta, C., Bura, S. A., Aracil-Fernández, A., Manzanares, J., and Maldonado, R. (2013). Role of CB1 and CB2 cannabinoid receptors in the development of joint pain induced by monosodium iodoacetate. Pain. 154, 160-174. doi: 10.1016/j.pain.2012.10.009

Larsson, K. P., Peltonen, H. M., Bart, G., Louhivuori, L. M., Penttonen, A., Antikainen, M., et al. (2005). Orexin-A-induced Ca2+ entry: evidence for involvement of trpc channels and protein kinase C regulation. J. Biol. Chem. 280, 1771-1781. doi: 10.1074/jbc.M406073200

Lawrence, A. J., Cowen, M. S., Yang, H. J., Chen, F., and Oldfield, B. (2006). The orexin system regulates alcohol-seeking in rats. Br. J. Pharmacol. 148, 752-759. doi: 10.1038/sj.bjp.0706789

Lecca, D., Cacciapaglia, F., Valentini, V., and Di Chiara, G. (2006). Monitoring extracellular dopamine in the rat nucleus accumbens shell and core during acquisition and maintenance of intravenous WIN 55,212-2 self-administration. Psychopharmacology (Berl.) 188, 63-74. doi: 10.1007/s00213-0060475-3
Lee, H. J., and Chiou, L. C. (2009). Orexins reduce nociceptive response via endocannabinoid signaling in the midbrain ventrolateral periaqueductal gray. Chicago, IL., USA. Neuroscience Prog. No. 458.14.

Lee, M. G., Hassani, O. K., and Jones, B. E. (2005). Discharge of identified orexin/hypocretin neurons across the sleep-waking cycle. J. Neurosci. 25, 6716-6720. doi: 10.1523/JNEUROSCI.188705.2005

LeSage, M. G., Perry, J. L., Kotz, C. M., Shelley, D., and Corrigall, W. A. (2010). Nicotine self-administration in the rat: effects of hypocretin antagonists and changes in hypocretin mRNA. Psychopharmacology (Berl.) 209, 203-212. doi: 10.1007/s00213-010-1792-0

Li, Y., Gao, X. B., Sakurai, T., and van den Pol, A. N. (2002). Hypocretin/Orexin excites hypocretin neurons via a local glutamate neuron-A potential mechanism for orchestrating the hypothalamic arousal system. Neuron 36, 1169-1181. doi: 10.1016/S0896-6273(02)01132-7

Lichtman, A. H., Cook, S. A., and Martin, B. R. (1996). Investigation of brain sites mediating cannabinoid-induced antinociception in rats: evidence supporting periaqueductal gray involvement. J. Pharmacol. Exp. Ther. 276, 585-593.

Lichtman, A. H., and Martin, B. R. (1991). Spinal and supraspinal components of cannabinoid-induced antinociception. J. Pharmacol. Exp. Ther. 258, 517-523.

Lin, L., Faraco, J., Li, R., Kadotani, H., Rogers, W., Lin, X., et al. (1999). The sleep disorder canine narcolepsy is caused by a mutation in the hypocretin (orexin) receptor 2 gene. Cell 98, 365-376. doi: 10.1016/S0092-8674(00) 81965-0

Liu, R. J., van den Pol, A. N., and Aghajanian, G. K. (2002). Hypocretins (orexins) regulate serotonin neurons in the dorsal raphe nucleus by excitatory direct and inhibitory indirect actions. J. Neurosci. 22, 9453-9464.

Ma, X., Zubcevic, L., Brüning, J. C., Ashcroft, F. M., and Burdakov, D. (2007). Electrical inhibition of identified anorexigenic POMC neurons by orexin/hypocretin. J. Neurosci. 27, 1529-1533. doi: 10.1523/JNEUROSCI.358306.2007

Maccioni, P., Pes, D., Carai, M. A., Gessa, G. L., and Colombo, G. (2008). Suppression by the cannabinoid CB1 receptor antagonist, rimonabant, of the reinforcing and motivational properties of a chocolate-flavoured beverage in rats. Behav. Pharmacol. 19, 197-209. doi: 10.1097/FBP.0b013e3282 fe8888

Mackie, K. (2005). Distribution of cannabinoid receptors in the central and peripheral nervous system. Handb. Exp. Pharmacol. 168, 299-325. doi: 10.1007/3-54026573-2_10

Mahler, S. V., Smith, K. S., and Berridge, K. C. (2007). Endocannabinoid hedonic hotspot for sensory pleasure: anandamide in nucleus accumbens shell enhances "liking" of a sweet reward. Neuropsychopharmacology 32, 2267-2278. doi: 10.1038/sj.npp.1301376

Mahler, S. V., Smith, R. J., and Aston-Jones, G. (2013). Interactions between VTA orexin and glutamate in cue-induced reinstatement of cocaine seeking in rats. Psychopharmacology (Berl.) 226, 687-698. doi: 10.1007/s00213-0122681-5

Mahler, S. V., Smith, R. J., Moorman, D. E., Sartor, G. C., and Aston-Jones, G. (2012). Multiple roles for orexin/hypocretin in addiction. Prog. Brain Res. 198, 79-121. doi: 10.1016/B978-0-444-59489-1.00007-0

Maldonado, R., Berrendero, F., Ozaita, A., and Robledo, P. (2011). Neurochemical basis of cannabis addiction. Neuroscience 181, 1-17. doi: 10.1016/j.neuroscience.2011.02.035

Maldonado, R., Valverde, O., and Berrendero, F. (2006). Involvement of the endocannabinoid system in drug addiction. Trends Neurosci. 29, 225-232. doi: 10.1016/j.tins.2006.01.008

Marcus, J. N., Aschkenasi, C. J., Lee, C. E., Chemelli, R. M., Saper, C. B., Yanagisawa, M. et al. (2001). Differential expression of orexin receptors 1 and 2 in the rat brain. J. Comp. Neurol. 435, 6-25. doi: 10.1002/ cne. 1190

Martin, B. R. (1986). Cellular effects of cannabinoids. Pharmacol. Rev. 38, 45-74.

Martin, M., Ledent, C., Parmentier, M., Maldonado, R., and Valverde, O. (2000). Cocaine, but not morphine, induces conditioned place preference and sensitization to locomotor responses in CB1 knockout mice. Eur. J. Neurosci. 11, 4038-4046. doi: 10.1046/j.1460-9568.2000. 00287.x 
Martin, W. J., Lai, N. K., Patrick, S. L., Tsou, K., and Walker, J. M. (1993). Antinociceptive actions of cannabinoids following intraventricular administration in rats. Brain Res. 629, 300-304. doi: 10.1016/0006-8993(93) 91334-O

Matsuda, L. A., Lolait, S. J., Brownstein, M. J., Young, A. C., and Bonner, T. I. (1990). Structure of a cannabinoid receptor and functional expression of the cloned cDNA. Nature 346, 561-564. doi: 10.1038/346561a0

McGinty, D. J., and Harper, R. M. (1976). Dorsal raphe neurons: depression of firing during sleep in cats. Brain Res. 101, 569-575. doi: 10.1016/00068993(76)90480-7

Melck, D., Rueda, D., Galve-Roperh, I., De Petrocellis, L., Guzmán, M., and Di Marzo, V. (1999). Involvement of the CAMP/protein kinase A pathway and of mitogen-activated protein kinase in the anti-proliferative effects of anandamide in human breast cancer cells. FEBS Lett. 463, 235-240. doi: 10.1016/S00145793(99)01639-7

Melis, M., Pistis, M., Perra, S., Muntoni, A. L., Pillolla, G., and Gessa, G. L. (2004). Endocannabinoids mediate presynaptic inhibition of glutamatergic transmission in rat ventral tegmental area dopamine neurons through activation of CB1 receptors. J. Neurosci. 24, 53-62. doi: 10.1523/JNEUROSCI.4503-03.2004

Mendizábal, V., Zimmer, A., and Maldonado, R. (2006). Involvement of kappa/dynorphin system in WIN 55,212-2 self-administration in mice. Neuropsychopharmacology 31, 1957-1966. doi: 10.1038/sj.npp.1300957

Millns, P. J., Chapman, V., and Kendall, D. A. (2001). Cannabinoid inhibition of the capsaicin-induced calcium response in rat dorsal root ganglion neurones. Br. J. Pharmacol. 132, 969-971. doi: 10.1038/sj.bjp.0703919

Mobarakeh, J. I., Takahashi, K., Sakurada, S., Nishino, S., Watanabe, H., Kato, M., et al. (2005). Enhanced antinociception by intracerebroventricularly and intrathecally-administered orexin A and B (hypocretin-1 and -2) in mice. Peptides 26, 767-777. doi: 10.1016/j.peptides.2005.01.001

Moorman, D. E., and Aston-Jones, G. (2009). Orexin-1 receptor antagonism decreases ethanol consumption and preference selectively in highethanol-preferring Sprague-Dawley rats. Alcohol. 43, 379-386. doi: 10.1016/j.alcohol.2009.07.002

Muccioli, G. G. (2010). Endocannabinoid biosynthesis and inactivation, from simple to complex. Drug Discov. Today 15, 474-483. doi: 10.1016/j.drudis.2010.03.007

Munro, S., Thomas, K. L., and Abu-Shaar, M. (1993). Molecular characterization of a peripheral receptor for cannabinoids. Nature 365, 61-65. doi: 10.1038/365061a0

Murai, Y., and Akaike, T. (2005). Orexins cause depolarization via nonselective cationic and $\mathrm{K}+$ channels in isolated locus coeruleus neurons. Neurosci. Res. 51, 55-65. doi: 10.1016/j.neures.2004.09.005

Murillo-Rodríguez, E., Cabeza, R., Méndez-Díaz, M., Navarro, L., and ProspéroGarcía, O. (2001). Anandamide-induced sleep is blocked by SR141716A, a CB1 receptor antagonist and by U73122, a phospholipase C inhibitor. Neuroreport 12, 2131-2136. doi: 10.1097/00001756-200107200-00018

Murray, R. M., Morrison, P. D., Henquet, C., and Di Forti, M. (2007). Cannabis, the mind and society: the hash realities. Nat. Rev. Neurosci. 8, 885-895. doi: $10.1038 / \mathrm{nrn} 2253$

Nair, S. G., Golden, S. A., and Shaham, Y. (2008). Differential effects of the hypocretin 1 receptor antagonist SB 334867 on high-fat food self-administration and reinstatement of food seeking in rats. Br. J. Pharmacol. 154, 406-416. doi: 10.1038/bjp.2008.3

Narita, M., Nagumo, Y., Hashimoto, S., Narita, M., Khotib, J., Miyatake, M., et al. (2006). Direct involvement of orexinergic systems in the activation of the mesolimbic dopamine pathway and related behaviors induced by morphine. J. Neurosci. 26, 398-405. doi: 10.1523/JNEUROSCI.276105.2006

Navarro, M., Carrera, M. R., Del Arco, I., Trigo, J. M., Koob, G. F., and Rodríguez de Fonseca, F. (2004). Cannabinoid receptor antagonist reduces heroin selfadministration only in dependent rats. Eur. J. Pharmacol. 501, 235-237. doi: 10.1016/j.ejphar.2004.08.022

Navarro, M., Carrera, M. R., Fratta, W., Valverde, O., Cossu, G., Fattore, L., et al. (2001). Functional interaction between opioid and cannabinoid receptors in drug self-administration. J. Neurosci. 21, 5344-5350.

Núñez, E., Benito, C., Pazos, M. R., Barbachano, A., Fajardo, O., González, S., et al. (2004). Cannabinoid CB2 receptors are expressed by perivascular microglial cells in the human brain: an immunohistochemical study. Synapse 53, 208-213. doi: 10.1002/syn.20050
Onaivi, E. S., Ishiguro, H., Gong, J. P., Patel, S., Perchuk, A., Meozzi, P. A., et al. (2006). Discovery of the presence and functional expression of cannabinoid CB2 receptors in brain. Ann. N.Y. Acad. Sci. 1074, 514-536. doi: 10.1196/annals.1369.052

Parolaro, D., Rubino, T., Viganò, D., Massi, P., Guidali, C., and Realini, N. (2010). Cellular mechanisms underlying the interaction between cannabinoid and opioid system. Curr. Drug Targets 11, 393-405. doi: 10.2174/138945010790 980367

Pérez-Morales, M., De La Herrán-Arita, A. K., Méndez-Díaz, M., Ruiz-Contreras, A. E., Drucker-Colín, R., and Prospéro-García, O. (2013). 2-AG into the lateral hypothalamus increases REM sleep and cFos expression in melanin concentrating hormone neurons in rats. Pharmacol. Biochem. Behav. 108, 1-7. doi: 10.1016/j.pbb.2013.04.006

Pertwee, R. G., Howlett, A. C., Abood, M. E., Alexander, S. P., Di Marzo, V., Elphick, M. R., et al. (2010). International Union of Basic and Clinical Pharmacology. LXXIX. Cannabinoid receptors and their ligands: beyond CB1 and CB2. Pharmacol. Rev. 62, 588-631. doi: 10.1124/pr.110.003004

Petrosino, S., Palazzo, E., de Novellis, V., Bissogno, T., Rossi, F., Maione, S., et al. (2007). Changes in spinal and supraspinal endocannabinoid levels in neuropathic rats. Neuropharmacology 52, 415-422. doi: 10.1016/j.neuropharm.2006.08.011

Peyron, C., Tighe, D. K., van den Pol, A. N., de Lecea, L., Heller, H. C., Sutcliffe, J. G. et al. (1998). Neurons containing hypocretin (orexin) project to multiple neuronal systems. J. Neurosci. 18, 9996-10015.

Pissios, P., Bradley, R. L., and Maratos-Flier, E. (2006). Expanding the scales: the multiple roles of $\mathrm{MCH}$ in regulating energy balance and other biological functions. Endocr. Rev. 27, 606-620. doi: 10.1210/er.2006-0021

Plaza-Zabala, A., Maldonado, R., and Berrendero, F. (2012). The hypocretin/orexin system: implications for drug reward and relapse. Mol. Neurobiol. 45, 424-439. doi: 10.1007/s12035-012-8255-z

Portas, C. M., Thakkar, M., Rainnie, D., and McCarley, R. W. (1996). Microdialysis perfusion of 8-hydroxy-2-(di-n-propylamino)tetralin (8-OH-DPAT) in the dorsal raphe nucleus decreases serotonin release and increases rapid eye movement sleep in the freely moving cat. J. Neurosci. 16, 2820-2828.

Porter, A. C., Sauer, J. M., Knierman, M. D., Becker, G. W., Berna, M. J., Bao, J., et al. (2002). Characterization of a novel endocannabinoid, virodhamine, with antagonist activity at the CB1 receptor. J. Pharmacol. Exp. Ther. 301, 1020-1024. doi: 10.1124/jpet.301.3.1020

Racz, I., Nadal, X., Alferink, J., Baños, J. E., Rehnelt, J., Martín, M., et al. (2008). Crucial role of $\mathrm{CB}(2)$ cannabinoid receptor in the regulation of central immune responses during neuropathic pain. J. Neurosci. 28, 12125-12135. doi: 10.1523/JNEUROSCI.3400-08.2008.

Ren, K., and Dubner, R. (2008). Neuron-glia crosstalk gets serious: role in pain hypersensitivity. Curr. Opin. Anaesthesiol. 21, 570-579. doi: 10.1097/ACO.0b013e32830edbdf

Richard, D., Guesdon, B., and Timofeeva, E. (2009). The brain endocannabinoid system in the regulation of energy balance. Best Pract. Res. Clin. Endocrinol. Metab. 23, 17-32. doi: 10.1016/j.beem.2008.10.007

Riegel, A. C., and Lupica, C. R. (2004). Independent presynaptic and postsynaptic mechanisms regulate endocannabinoid signaling at multiple synapses in the ventral tegmental area. J. Neurosci. 24, 11070-11078. doi: 10.1523/JNEUROSCI.3695-04.2004

Robledo, P., Berrendero, F., Ozaita, A., and Maldonado, R. (2008). Advances in the field of cannabinoid-opioid cross-talk. Addict. Biol. 13, 213-224. doi: 10.1111/j.1369-1600.2008.00107.x

Rotter, A., Bayerlein, K., Hansbauer, M., Weiland, J., Sperling, W., Kornhuber, J., et al. (2012). Orexin A expression and promoter methylation in patients with cannabis dependence in comparison to nicotine-dependent cigarette smokers and nonsmokers. Neuropsychobiology 66, 126-133. doi: 10.1159/0003 39457

Rueda-Orozco, P. E., Soria-Gómez, E., Montes-Rodríguez, C. J., Pérez-Morales, M., and Prospéro-García, O. (2010). Intrahippocampal administration of anandamide increases REM sleep. Neurosci. Lett. 473, 158-162. doi: 10.1016/j.neulet.2010.02.044

Sakurai, T., Amemiya, A., Ishii, M., Matsuzaki, I., Chemelli, R. M., Tanaka, H. et al. (1998). Orexins and orexin receptors: a family of hypothalamic neuropeptides and $G$ protein-coupled receptors that regulate feeding behavior. Cell 92, 573-585. doi: 10.1016/S0092-8674(00) 80949-6 
Sánchez, M. G., Ruiz-Llorente, L., Sánchez, A. M., and Díaz-Laviada, I. (2003). Activation of phosphoinositide 3-kinase/PKB pathway by $\mathrm{CB}(1)$ and $\mathrm{CB}(2)$ cannabinoid receptors expressed in prostate PC-3 cells. Involvement in Raf-1 stimulation and NGF induction. Cell Signal. 15, 851-859. doi: 10.1016/S08986568(03)00036-6

Sanchis-Segura, C., Cline, B. H., Marsicano, G., Lutz, B., and Spanagel, R. (2004). Reduced sensitivity to reward in CB1 knockout mice. Psychopharmacology (Berl.) 176, 223-232. doi: 10.1007/s00213-004-1877-8

Santucci, V., Storme, J. J., Soubrié, P., and Le Fur, G. (1996). Arousal-enhancing properties of the CB1 cannabinoid receptor antagonist SR 141716A in rats as assessed by electroencephalographic spectral and sleep-waking cycle analysis. Life Sci. 58, PL103- PL110. doi: 10.1016/0024-3205(95)02319-4

Saper, C. B., Chou, T. C., and Elmquist, J. K. (2002). The need to feed: homeostatic and hedonic control of eating. Neuron 36, 199-211 doi: 10.1016/S08966273(02)00969-8

Seagard, J. L., Hopp, F. A., Hillard, C. J., and Dean, C. (2005). Effects of endocannabinoids on discharge of baroreceptive NTS neurons. Neurosci. Lett. 381, 334-339. doi: 10.1016/j.neulet.2005.02.044

Sharf, R., Sarhan, M., Brayton, C. E., Guarnieri, D. J., Taylor, J. R., and DiLeone, R. J. (2010). Orexin signaling via the orexin 1 receptor mediates operant responding for food reinforcement. Biol. Psychiatry 67, 753-760. doi: 10.1016/j.biopsych.2009.12.035

Shiraishi, T., Oomura, Y., Sasaki, K., and Wayner, M. J. (2000). Effects of leptin and orexin-A on food intake and feeding related hypothalamic neurons. Physiol. Behav. 71, 251-261. doi: 10.1016/S0031-9384(00)00341-3

Slipetz, D. M., O’Neill, G. P., Favreau, L., Dufresne, C., Gallant, M., Gareau, Y., et al. (1995). Activation of the human peripheral cannabinoid receptor results in inhibition of adenylyl cyclase. Mol. Pharmacol. 48, 352-361.

Smart, D., Sabido-David, C., Brough, S. J., Jewitt, F., Johns, A., Porter, R. A., et al. (2001). SB-334867-A: the first selective orexin-1 receptor antagonist. $\mathrm{Br}$. J. Pharmacol. 132, 1179-1182. doi: 10.1038/sj.bjp.0703953

Smith, R. J., and Aston-Jones, G. (2012). Orexin/hypocretin 1 receptor antagonist reduces heroin self-administration and cue-induced heroin seeking. Eur. J. Neurosci. 35, 798-804. doi: 10.1111/j.1460-9568.2012. 08013.x

Soria, G., Mendizábal, V., Touriño, C., Robledo, P., Ledent, C., Parmentier, M., et al. (2005). Lack of CB1 cannabinoid receptor impairs cocaine self-administration. Neuropsychopharmacology 30, 1670-1680. doi.org/10.1038/sj.npp. 1300707

Sugiura, T., Kondo, S., Sukagawa, A., Nakane, S., Shinoda, A., Itoh, K., et al. (1995). 2-Arachidonoylglycerol: a possible endogenous cannabinoid receptor ligand in brain. Biochem. Biophys. Res. Commun. 215, 89-97. doi: 10.1006/bbrc.1995.2437

Tang, J., Chen, J., Ramanjaneya, M., Punn, A., Conner, A. C., and Randeva, H. S. (2008). The signalling profile of recombinant human orexin-2 receptor. Cell Signal. 20, 1651-1661. doi: 10.1016/j.cellsig.2008.05.010

Taslimi, Z., Haghparast, A., Hassanpour-Ezatti, M., and Safari, M. S. (2011). Chemical stimulation of the lateral hypothalamus induces conditioned place preference in rats: involvement of $\mathrm{OX} 1$ and $\mathrm{CB} 1$ receptors in the ventral tegmental area. Behav. Brain Res. 217, 41-46. doi: 10.1016/j.bbr.2010.10.007

Tsujino, N., and Sakurai, T. (2009). Orexin/hypocretin: a neuropeptide at the interface of sleep, energy homeostasis, and reward system. Pharmacol. Rev. 61, 162-176. doi: 10.1124/pr.109.001321

Tsuneki, H., Wada, T., and Sasaoka, T. (2010). Role of orexin in the regulation of glucose homeostasis. Acta Physiol. (Oxf.) 198, 335-348. doi: 10.1111/j.17481716.2009.02008.x

Turunen, P. M., Jäntti, M. H., and Kukkonen, J. P. (2012). OX1 orexin/hypocretin receptor signaling through arachidonic acid and endocannabinoid release. Mol. Pharmacol. 82, 156-167. doi: 10.1124/mol.112.078063

Urbańska, A., Sokołowska, P., Woldan-Tambor, A., Biegañska, K., Brix, B., Jöhren, O., et al. (2012). Orexins/hypocretins acting at Gi protein-coupled OX 2 receptors inhibit cyclic AMP synthesis in the primary neuronal cultures. J. Mol. Neurosci. 46, 10-17. doi: 10.1007/s12031-011-9526-2

Valassi, E., Scacchi, M., and Cavagnini, F. (2008). Neuroendocrine control of food intake. Nutr. Metab. Cardiovasc. Dis. 18, 158-168. doi: 10.1016/j.numecd.2007.06.004

van den Pol, A. N., Gao, X. B., Obrietan, K., Kilduff, T. S., and Belousov, A. B. (1998). Presynaptic and postsynaptic actions and modulation of neuroendocrine neurons by a new hypothalamic peptide, hypocretin/orexin. J. Neurosci. $18,7962-7671$.
Van Sickle, M. D., Duncan, M., Kingsley, P. J., Mouihate, A., Urbani, P., Mackie, K., et al. (2005). Identification and functional characterization of brainstem cannabinoid CB2 receptors. Science 310, 329-332. doi: 10.1126/science. 1115740

Vásquez, C., Navarro-Polanco, R. A., Huerta, M., Trujillo, X., Andrade, F., TrujilloHernández, B., et al. (2003). Effects of cannabinoids on endogenous $\mathrm{K}+$ and Ca2+ currents in HEK293 cells. Can. J. Physiol. Pharmacol. 81, 436-442. doi: 10.1139/y03-055

Vaughan, C. W., Connor, M., Bagley, E. E., and Christie, M. J. (2000). Actions of cannabinoids on membrane properties and synaptic transmission in rat periaqueductal gray neurons in vitro. Mol. Pharmacol. 57, 288-295.

Verty, A. N., Allen, A. M., and Oldfield, B. J. (2009). The effects of rimonabant on brown adipose tissue in rat: implications for energy expenditure. Obesity (Silver Spring). 17, 254-261. doi: 10.1038/oby.2008.509

Vittoz, N. M., Schmeichel, B., and Berridge, C. W. (2008). Hypocretin/orexin preferentially activates caudomedial ventral tegmental area dopamine neurons. Eur. J. Neurosci. 28, 1629-1640. doi: 10.1111/j.1460-9568.2008.06453.x

Wang, B., You, Z. B., and Wise, R. A. (2009). Reinstatement of cocaine seeking by hypocretin (orexin) in the ventral tegmental area: independence from the local corticotropin-releasing factor network. Biol. Psychiatry. 65, 857-862. doi: 10.1016/j.biopsych.2009.01.018

Wang, L., Liu, J., Harvey-White, J., Zimmer, A., and Kunos, G. (2003). Endocannabinoid signaling via cannabinoid receptor 1 is involved in ethanol preference and its age-dependent decline in mice. Proc. Natl. Acad. Sci. U.S.A. 100, 1393-1398. doi: 10.1073/pnas.0336351100

Ward, R. J., Pediani, J. D., and Milligan, G. (2011a). Heteromultimerization of cannabinoid $\mathrm{CB}(1)$ receptor and orexin $\mathrm{OX}(1)$ receptor generates a unique complex in which both protomers are regulated by orexin A. J. Biol. Chem. 286, 37414-37428. doi: 10.1074/jbc.M111.287649

Ward, R. J., Pediani, J. D., and Milligan, G. (2011b). Ligand-induced internalization of the orexin $\mathrm{OX}(1)$ and cannabinoid $\mathrm{CB}(1)$ receptors assessed via N-terminal SNAP and CLIP-tagging. Br. J. Pharmacol. 162, 1439-1452. doi: 10.1111/j.14765381.2010.01156.x

Watanabe, S., Kuwaki, T., Yanagisawa, M., Fukuda, Y., and Shimoyama. M. (2005). Persistent pain and stress activate pain-inhibitory orexin pathways. Neuroreport 16, 5-8. doi: 10.1097/00001756-200501190-00002

Williams, C. M., and Kirkham, T. C. (1999). Anandamide induces overeating: mediation by central cannabinoid (CB1) receptors. Psychopharmacology (Berl.) 143, 315-317. doi: 10.1007/s002130050953

Williams, C. M., Rogers, P. J., and Kirkham, T. C. (1998). Hyperphagia in pre-fed rats following oral delta9-THC. Physiol. Behav. 65, 343-346. doi: 10.1016/S0031-9384(98)00170-X

Willie, J. T., Chemelli, R. M., Sinton, C. M., Tokita, S., Williams, S. C., Kisanuki, Y. Y., et al. (2003). Distinct narcolepsy syndromes in Orexin receptor-2 and Orexin null mice: molecular genetic dissection of Non-REM and REM sleep regulatory processes. Neuron 38, 715-730. doi: 10.1016/S0896-6273(03) 00330-1

Wilson-Poe, A. R., Morgan, M. M., Aicher, S. A., and Hegarty, D. M. (2012). Distribution of CB1 cannabinoid receptors and their relationship with muopioid receptors in the rat periaqueductal gray. Neuroscience 213, 191-200. doi: 10.1016/j.neuroscience.2012.03.038

Wise, R. A. (2004). Dopamine, learning and motivation. Nat. Rev. Neurosci. 5, 483-94. doi: 10.1038/nrn1406

Wittmann, G., Deli, L., Kalló, I., Hrabovszky, E., Watanabe, M., Liposits, Z., et al. (2007). Distribution of type 1 cannabinoid receptor (CB1)-immunoreactive axons in the mouse hypothalamus. J. Comp. Neurol. 503, 270-279. doi: $10.1002 /$ cne. 21383

Woldan-Tambor, A., Biegańska, K., Wiktorowska-Owczarek, A., and Zawilska, J. B. (2011). Activation of orexin/hypocretin type 1 receptors stimulates cAMP synthesis in primary cultures of rat astrocytes. Pharmacol Rep. 63, 717-723.

Xie, X., Wisor, J. P., Hara, J., Crowder, T. L., LeWinter, R., Khroyan, T. V., et al. (2008). Hypocretin/orexin and nociceptin/orphanin FQ coordinately regulate analgesia in a mouse model of stress-induced analgesia. J. Clin. Invest. 118, 2471-2481. doi: 10.1172/JCI35115

Yamamoto, T., Nozaki-Taguchi, N., and Chiba, T. (2002). Analgesic effect of intrathecally administered orexin-A in the rat formalin test and in the rat hot plate test. Br. J. Pharmacol. 137, 170-176. doi: 10.1038/sj.bjp.0704851 
Yamanaka, A., Beuckmann, C. T., Willie, J. T., Hara, J., Tsujino, N., Mieda, M., et al. (2003). Hypothalamic orexin neurons regulate arousal according to energy balance in mice. Neuron 38, 701-713. doi: 10.1016/S0896-6273(03) 00331-3

Yamanaka, A., Kunii, K., Nambu, T., Tsujino, N., Sakai, A., Matsuzaki, I., et al. (2000). Orexin-induced food intake involves neuropeptide $\mathrm{Y}$ pathway. Brain Res. 859, 404-409. doi: 10.1016/S0006-8993(00) 02043-6

Yamanaka, A., Sakurai, T., Katsumoto, T., Yanagisawa, M., and Goto, K. (1999). Chronic intracerebroventricular administration of orexin-A to rats increases food intake in daytime, but has no effect on body weight. Brain Res. 849, 248-252. doi: 10.1016/S0006-8993(99)01905-8

Yan, J. A., Ge, L., Huang, W., Song, B., Chen, X. W., and Yu, Z. P. (2008). Orexin affects dorsal root ganglion neurons: a mechanism for regulating the spinal nociceptive processing. Physiol. Res. 57, 797-800.

Yang, B., and Ferguson, A. V. (2002). Orexin-A depolarizes dissociated rat area postrema neurons through activation of a nonselective cationic conductance. J. Neurosci. 22, 6303-6308.

Yang, B., and Ferguson, A. V. (2003). Orexin-A depolarizes nucleus tractus solitarius neurons through effects on nonselective cationic and $\mathrm{K}+$ conductances. $J$. Neurophysiol. 89, 2167-2175. doi: 10.1152/jn.01088.2002
Yang, B., Samson, W. K., and Ferguson, A. V. (2003). Excitatory effects of orexin-A on nucleus tractus solitarius neurons are mediated by phospholipase $\mathrm{C}$ and protein kinase C. J. Neurosci. 23, 6215-6222.

Conflict of Interest Statement: The authors declare that the research was conducted in the absence of any commercial or financial relationships that could be construed as a potential conflict of interest.

Received: 30 October 2013; paper pending published: 21 November 2013; accepted: 09 December 2013; published online: 20 December 2013.

Citation: Flores Á, Maldonado R and Berrendero F (2013) Cannabinoid-hypocretin cross-talk in the central nervous system: what we know so far. Front. Neurosci. 7:256. doi: 10.3389/fnins.2013.00256

This article was submitted to Neuropharmacology, a section of the journal Frontiers in Neuroscience.

Copyright (c) 2013 Flores, Maldonado and Berrendero. This is an open-access article distributed under the terms of the Creative Commons Attribution License (CC BY). The use, distribution or reproduction in other forums is permitted, provided the original author(s) or licensor are credited and that the original publication in this journal is cited, in accordance with accepted academic practice. No use, distribution or reproduction is permitted which does not comply with these terms. 